Portland State University

PDXScholar

$1-1-1984$

\title{
Effective acquisition of basic skills: an elementary schools program
}

Linda L. Terhark

Portland State University

Follow this and additional works at: https://pdxscholar.library.pdx.edu/open_access_etds Let us know how access to this document benefits you.

\section{Recommended Citation}

Terhark, Linda L., "Effective acquisition of basic skills: an elementary schools program" (1984). Dissertations and Theses. Paper 419.

https://doi.org/10.15760/etd.419

This Dissertation is brought to you for free and open access. It has been accepted for inclusion in Dissertations and Theses by an authorized administrator of PDXScholar. Please contact us if we can make this document more accessible: pdxscholar@pdx.edu. 


\title{
EFFECTIVE ACQUISITION OF BASIC SKILLS: \\ AN ELEMENTARY SCHOOLS PROGRAM
}

\author{
By \\ Linda L. Terhark
}

A dissertation submitted in partial fulfillment of the requirements for the degree of

DOCTOR OF EDUCATION

in

PUBLIC SCHOOL ADMINISTRATION AND SUPERVISION

Portland State University

The University of Oregon

1984 
TO THE OFFICE OF GRADUATE STUDIES AND RESEARCH:

The members of the Committee approve the dissertation of Linda L. Terhark, presented May 21, 1984.

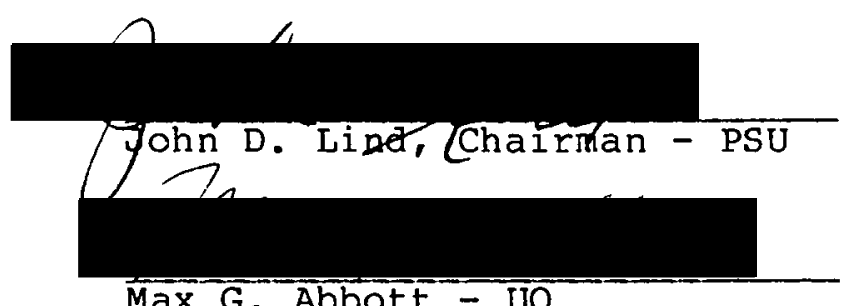

Max G. Abbott - UO

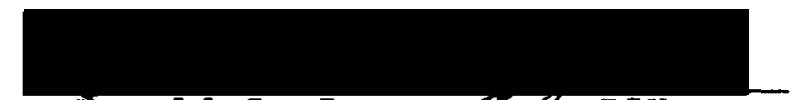

Harold C. Jorgengend- PSU

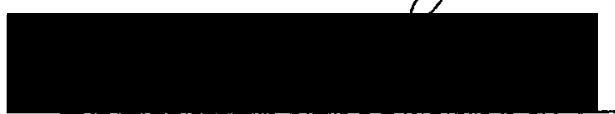

Loyded W. Hales - PSU

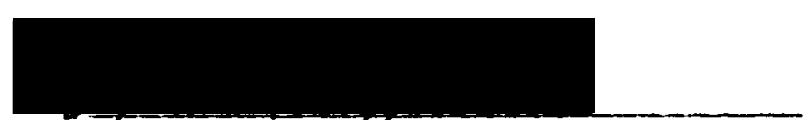

Robert E. Jönes - PSU

\section{APPROVED :} George V. Guy, Bi-Univerg ty Program Coordinator (Portland
State University)

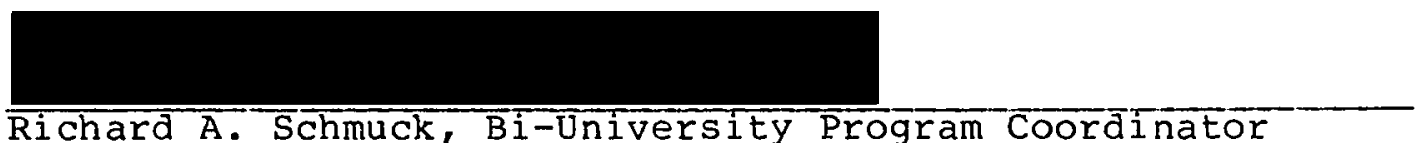
(University of Oregon)

Donald J. Lef, Eean, of the School of Education (Portiand State University)

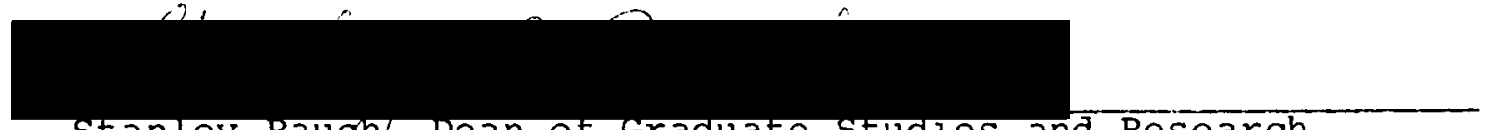

stanley Raugh/, Dean of Graduate studies and Research (Portland State University) 
AN ABSTRACT OF THE DISSERTATION OF Linda Terhark for the Doctor of Education in Public School Administration and Supervision presented May 21, 1984

Title: Effective Acquisition of Basic Skills: An Elementary Schools Program.

APPROVED BY MEMBERS OF THE DISSERTATION COMMITTEE:

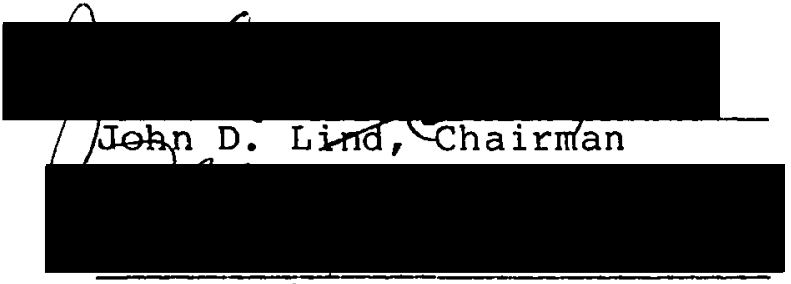

Max G. Abbott

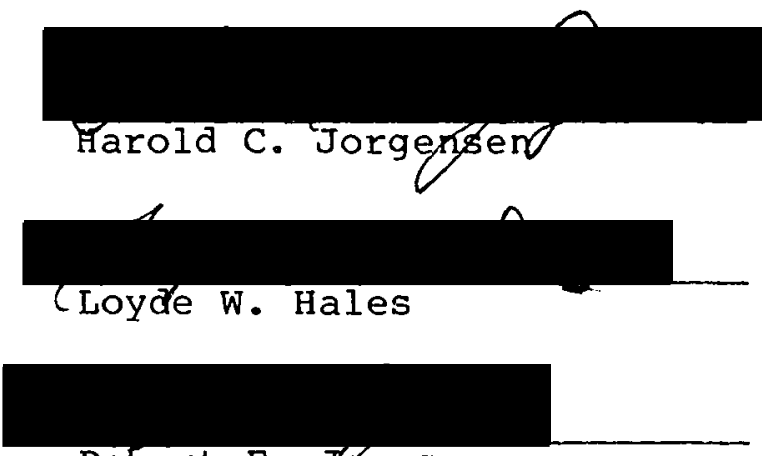

Robert E. Iones

The purpose of this study was to investigate and to determine the effectiveness of the Basic Skilis Program. This was a program developed at Clackamas Elementary School that implemented many of the effective school characteristics along with analyzing low-achievement areas in the California Achievement Test and organizing an instructional program that would teach to those low areas. 
This study compared achievement test results from the Spring of 1982 for grades four, five, and six (approximately 140 students) with achievement test results from the spring of 1983. The control group took the California Achievement Test the year before the treatment group; during the spring of 1981 they took the pretest, and in the spring of 1982 they took the posttest.

The treatment to improve low areas as determined by the California Achievement Test results of Spring, 1982, consisted of teachers administering extra work sheets that covered the deficient skills, a homework program, six week teacher grade level meetings to analyze progress and strand tests that helped teachers evaluate the students acquisition of the skill taught.

Many effective school characteristics were incorporated into the program. The principal set high expectations for student achievement and became active in instruction by leading the grade level meetings. The administration helped the teachers develop a homework policy and continued to inforce the already established discipline policy. A proactive plan to establish a positive school climate was developed which consisted of active student council, Citizen of the Month Assemblies, student of the week awards and staff social events. 
Two different statistical approaches were used to analyze the data from the study. Normal Curve Equivalents, NCE scores were used for the statistical analysis. A factorial multivariate analysis of variance on the $\mathrm{NCE}$ change scores for the control and treatment groups was performed. The multivariate statistical hypothesis was not rejected for interaction and grade level; it was rejected for the treatment within effect. Following the rejection of the multivariate statistical hypothesis concerning treatment, a factorial analysis of variance was performed on each dependent variable.

These tests lead to the conclusion that the treatment had no or negative effect on the student's achievement. students tended to show greater growth in the control year than they did in the treatment year. The reasons for the treatment or program failure can be better understood by analyzing the teacher attitudes about the program. The teachers were surveyed at the end of the treatment year. The survey results showed that the teachers did not like the program and the materials used in the program. Some of the teachers did not feel that a program to improve low areas should be developed. Some of the teachers did not believe that low students could be brought up to grade level through extra work. Teachers resented the administration's involvement in instruction and in the six week grade level meet- 
ings. They felt that they did not have enough time to teach an extra subject like basic skilis.

Change 1 iterature indicates that in order for change to be effective the people must value the change and have a say in how the change will take place. The development of the Basic skills program did not allow for enough teacher involvement or enough time for teachers to grow to value the change and thus be committed to the change.

A program to improve skills should provide for: 1) consensus decision making, 2) time for participants to grow to value the program, 3) time for reevaluation of the program, 4) inservice training that extends into the classroom so that teachers have support during the change, and 5) rewards and payoffs for the participants. Change is possible with these considerations but if elements are left out, as was the case in the Clackamas Elementary Basic Skills Program, the change will not occur. 
To my sister

Joie

"Be a up and a doing with a

heart for any fate......."

Thank you 


\section{ACKNOWLEDGEMENTS}

The writer is indebted to several groups and individuals. A very special thank you goes to the North Clackamas School District for allowing me to conduct this study at Clackamas Elementary School. The principal of Clackamas Elementary, Ron Orme was extremely helpful throughout the treatment year and during the writing of the dissertation. My Doctoral Advisory Committee was also helpful. Particularly valuable was the advice concerning interpretation of statistical data that I received from Loyde Hales and the support and suggestions given to me by my chairperson, John Lind.

Finally, the writer is grateful to Barbara wiegele whose ability on a word processor and helpful format suggestions has resulted in the completion of this study. 
DEDICATION . . . . . . . . . . . . . . i ii

ACKNOWLEDGEMENTS . . . . . . . . . . . . iv

LIST OF TABLES . . . . . . . . . . . . v viii

LIST OF FIGURES. . . . . . . . . . . . . $\mathrm{x}$

CHAPTER

I. INTRODUCTION TO THE STUDY. . . . . . . 1

Introduction . . . . . . . . . 1

Problem Statement. . ........ 3

The Research Model .......... 4

Organization of Remaining Chapters . . 6

Significance of the study. . . . . . 7

II. REVIEW OF the Literature . . . . . . . 9

Theoretical Foundations. . . . . . 9

Current School Effectiveness ... . . 11 Limitations of Effective School

Literature . . . . . . . . 17

The School as an Organization. . . . 24

Theory of Change . . . . . . . . 27

Change. Models. . . . . . . . . 28

Resistance to Change ....... 31

Change Agents $\quad . .0 . .0 .36$

Implementation of Change ..... 38

Portrait of An Effective School. . . . 43

Case Study of an Effective School. . 48

Summary of the Literature Review . . . 51

III. RESEARCH DESIGN AND METHODOLOGY. . . . 54

Introduction . . . . . . . . . 54

Treatment Procedures . . . . . . . . 55

Sampling Procedures and Considerations 62

Design of the Investigation . . . . 63

Statistical Treatment of Data. . . . 63 
IV. RESULTS AND ANALYSIS . . . . . . . . 66

Demographic Description of Treatment and

Control Groups . . . . . . . . . Socio-Economic status of the Population. . . . . . . . . . 67 Comparability of Treatment and Control Groups. . . . . . . . . 69

Procedures Used In Statistical Analysis ............ . 74

Analysis of Difference in NCE Gain Scores Between Control and Treatment Group . . . . . . . . . . . . Analysis of Variance, Multivariate Pre-Post GAin Scores

Analys is of Variance, Univariate

Test of Means......... . 77

Pre-to-Post $t$ on NCE Scores

Within Groups . . . . . . . . 79

Confidence Intervals on Mean Scores 84

Teachers Involvement and Attitudes . . . 84

Results of the Survey. . . . . . . 86

Teacher Participation in the Treatment

Program Measured by Time Spent . . . 97

Teachers' Suggestions for Changes in

Next Year's Program. ........ 100

V. GENERALIZATIONS CONCLUSIONS AND

RECOMMENDATIONS. . . . . . . . 103

Need for Effective School Improvement Programs. ........ 103

Study Reviewed . . . . . . . . 104

Comparability of the Treatment and

Control Groups . . . . . . . . 105

Statistical Analysis of the Study. - 105

Control Group Significant Results. . 107

Confidence Intervals on Mean Scores 107

Conclusions . . . . . . . . . 107

Teachers Involvement and Attitudes . 108

How Teachers' Attitudes Coincide with

known Attitudes of Teachers in

Effective Schools. . . . . . . 108

Do the Attitudes of Teachers Differ

From Grade Level to Grade Level? . 112

Teachers' Attitudes About Using the

Treatment Program. . . . . . . 112

Teachers' Suggestions for Change in Next Year's Programs ...... 113 
vi i

CHAPTER

PAGE

Limitations of the Study . . . . . 114

Change Research . . . . . . . . 115

Description of Clackamas Elementary

as An Organization . . . . . . 115

Theory of Change . . . . . . . . 117

Resistance to Change . . . . . . 120

Implementation of Change . . . . . 125

Comparison of Basic Skills Program

With Milwaukie RISE Project . . . . 126

Conclusions and Recommendations. . . 128

Problem Solving Method to Develop

Commitment . . • . . . . . . . . 129

The Linking Agent and Inservice . . 133

Changing Attitudes and Motivation . . 134

Finale . . . . . . . . . 136

REFERENCES . . . . . . . . . . . . . . 136

APPENDIX . . . . . . . . . . . . . . . 144

A Definition of NCE Scores from the

California Achievement Test . . . . . . 145

B Clackamas Elementary Basic Skills Program. . 148

C Teacher PRI Recording Sheet Form . . . . . 150

D Teacher PRI Recording Sheet Form . . . . . 152

E Clackamas Elementary Homework Program. •. . 154

F Clackamas Elementary Discipline Policy . . . 157

G Clackamas Elementary Time-Out Procedure. . 159

$H(1)$ Teacher Survey Given at End of Treatment Procedure . . . . . . . . . . . 161

$\mathrm{H}(2)$ Teacher Survey Given at End of Treatment Procedure . . . . . . . . . . 163 


\section{LIST OF TABLES}

TABLE

PAGE

I Comparison of Demographic Characteristics

of the Treatment and Control Groups. . . 68

II Dropouts from the Control and Treatment

Groups . . . . . . . . . . . . 70

II Lunch Pooled Grade Comparisons. • • . . 71

IV Dropout Rate Comparisons. . . . . . . 72

$V \quad t$ Test Between Groups on Pretest to Pretest Differences for Control and Treatment Groups . . . . . . . . . . . . . .

VI Manove on Grain Scores Between Control and Treatment Groups. . . . . . . . . . 76

VII Analysis of Variance on Mean Gain Scores Test of Significance For Sub Scales of the Treatment and Control Groups. . . . ..

VIII Student $t$ Test Pre-Post Growth within Groups on NCE Scores . . . . . . . 80

IX Student $t$ Test Pre-post Growth Within Groups on $\mathrm{NCE}^{-}$Scores . . . . . . . . . . .

$x$ Student $t$ Test Pre-Post Growth within Groups on NCE Scores . . . . . . . . . 82

XI Table of Means, Standard Deviations and Confidence Intervals on Gain Scores for the Treatment and Control Groups. • 85

XII Teacher Attitudes on Measuring Effectiveness Through Evaluation of Test Results. . . 87

XIII Teacher Attitudes and Expectations for student Achievement . . . . . . . . . 88

XIV Teacher Attitudes About Actual Instruction . 90

XV Teacher Attitudes About Parental Involvement . . . . . . . . . . . . 
XVI Teacher Attitudes About Principal Involvement............... 93

XVII Teacher Attitudes About the Basic Skills Program . . . . . . . . . . . 95

XVIII Teacher Attitudes About School Environment . 98

XIX Teacher Participation in the Treatment Measured by Time Spent. . . . . . . . 99 
LIST OF FIGURES

PAGE

FIGURE

1. Means on Gain Scores for Treatment and Control... . . . . . . . 83 


\section{CHAPTER I}

\section{INTRODUCTION}

In recent years educators have focused on research that indicates some schools are more effective than others, as measured by improvement students make on standardized achievement tests. An effective school, according to the research, is a school where students make significant growth in achievement--growth that can be attributed to the programs of that school and not normal maturation.

Educators today are feeling pressure as the taxpayers ask why it is costing more to educate fewer students, while the results, in terms of test scores, are lower than in the past. Professionals are saying the same things. Robert Sweet (1983) acting director of the National Institute of Education, stated that fifteen to twenty percent of high school graduates cannot read or write well enough to get jobs as cooks or mechanics. Justice Warren Burger (1983) maintains that a large percent of criminals cannot read or write and about 858 of the youth in the courts today cannot read. Elizabeth Johnson (1982), member of the Oregon Educational Coordinating Commission, 
wrote that there needs to be reform in education today in the areas of finance, public opinion, and education itself. She states that people have lost confidence in education and that taxpayers do not feel they are getting their money's worth.

During the 1970's the government responded to the decline in achievement of American school students by authorizing the National Institute of Education to spend fifty million dollars to determine the most effective educational practices. The result of this effort has produced a body of research on effective schools. The results of the research indicate that certain elements are commonly found in effective schools and that effective schools are identified by growth in achievement test scores.

In 1983 the National Commission on Excellence in Education warned, in an open letter to the American people, that our nation is at risk. The report was an imperative for educational reform and stated that "our once unchallenged predominance in commerce, industry, science, and technological innovation is being overtaken by competitors throughout the world" (p. 5). The report continues:

We report to the American people that while we can take justifiable pride in what our schools and colleges have historically accomplished and contributed to the United States and the well-being of its people, the educational foundations of our society are presently being eroded by a rising tide of mediocrity that threatens our very future 
as a Nation and a people. What was unimaginable a generation ago has begun to occur--others are matching and surpassing our educational attainments ( $p, 5)$.

Furthermore the Commission stated that "history is not kind to idlers" (p. 6) and if our nation is to be in the forefront, the educational system is going to have to reform. Education should strive for "excellence," which means that the individual learner should perform to the maximum limits of his/her ability. "Our goal must be to develop the talents of all to their fullest" (p. 12).

In order to accomplish this, the report made specific recommendations in the areas of curriculum content, standards and expectations, time spent teaching, teaching strategies, leadership, and fiscal support. Many of the recommendations are based on the conditions that were found in effective schools.

\section{Problem Statement}

As administrators gain knowledge of the effective school research and the variables that are present in an effective school, it is understandable that they want to implement these variables in order to build more effective schools. The assumption is that once a school is made aware of the seven to twelve key features, it can simply choose to adopt and implement them. However, the history of educational reform demonstrates that no matter how well 
planned, systematic interventions in schools are not always successful (Berman and McLaughlin, 1975). Given this information, there are several questions to be asked. How will the characteristics to be implemented affect the traditionally autonomous classroom teacher? How does the administrator get the staff to commit to a new program? How does the administrator educate his/her staff about the effective schools research? How does the administrator become the instructional leader and organize curriculum and establish clear goals? How does the administrator get parental involvement and district support? How does the administrator get teachers to maximize classroom learning time?

This study concerns one administrator's attempt to deal with some of these questions in order to improve a school's educational program by implementing some of the effective schools' variables in the context of an elementary school's Basic Skills Program.

\section{The Research Model}

The Basic Skills Program involved intact groups which were the existing fourth, fifth, and sixth grades from one school, Clackamas Elementary School. The control groups were the aforementioned intact groups during the 1981-82 school year, the year prior to program implementation; the experimental groups were comprised of students 
at the same grade levels during the year of program implementation (1982-83). At each grade level, the difference between the Fall and Spring NCE scores for each student was calculated for both the control and experimental groups; these differences were compared to determine if the changes in relative position within the norming sample differed for the control and experimental groups. Secondarily, each of the experimental and control groups was examined to see if the relative position in the norming sample was held constant (for the description of NCE scores see Appendix A).

The research hypothesis was: The treatment, the Basic Skills Program will make a significant difference in growth of students as measured on the California

Achievement Test from one spring to the next spring. The organization is test-treatment-test. Four low areas of achievement were identified in reading and math after the California Achievement Test results were analyzed in the Spring of 1982. A Basic Skills Program was then developed that would allow staff to concentrate on teaching to those low areas identified. In the spring of 1983, the California Achievement Test was given again and the areas that were emphasized in the Basic Skills Program were analyzed to see if the program significantly improved the students NCE scores. 


\section{Organization of Remaining Chapters}

Chapter II contains a review of the literature, describing and analyzing the contributions of effective school researchers who have conducted studies to determine variables that are present in effective schools. Research on change strategies and implementation of innovation is also reviewed.

Chapter III presents the literature relevant to the research methodology, the research methods and procedures, a description of the treatment, actual materials used, procedures implemented, analysis of test scores, and problems encountered by the investigator.

Chapter IV contains a presentation and analysis of the data, sampling procedures and considerations, comparability of treatment and control groups; the results of the study using a multivariate analysis of variances on the pretest to posttest NCE change score means; and t test of the differences between the pretest and posttest $\mathrm{NCE}$ score means within groups, pretest to pretest $t$-test on NCE score means between groups, confidence intervals on mean scores, and a chi-square on lunch data between groups, the latter three test being used as a check on the comparability of the comparison groups. Presentation of the results of a teacher survey that measured teacher involvement and attitudes was also included. This survey 
was used to determine the presents of any effective school variables.

Chapter $\mathrm{V}$ contains a summary of the study findings and presents conclusions about the findings. The treatment is analyzed with help from the teacher survey. The investigator makes recommendations to school administrators who might be making plans to implement an effective school program.

\section{Significance of the Study}

This study is significant in several ways. First, by designing and analyzing a model program, information can be obtained that wiil help other school administrators incorporate programs into their schools. However, it should be kept in mind that each new program would have to be modified to fit each particular school. The information on results and materials used are important in developing a more effective program in another school. Clune (1982) points out that school effectiveness literature provides for "goal definition" (what schools are to be like in order to be effective). However, suggestions for strategies for change based on organizational and implementation theory are less clear. He states that more research is needed to determine effective practices to use in the implementation phase of an improvement program. 
This study will add research that can be used to clarify the process of implementation.

Second, the results of this study will help the organizers of a Basic Skills Program to redesign the Program. The teacher suggestions for improvements, solicited from the teacher survey given at the end of the treatment year, may be used to help redesign the program for the following year.

Third, the School District can use the Basic Skilis Program as a model for other schools in the district and as a catalyst to motivate other schools to plan programs that choose to adopt more effective teaching strategies. 
CHAPTER II

REVIEW OF THE LITERATURE

The recent literature on school effectiveness concludes that certain characteristics do affect student academic achievement. The research suggests that a school's effectiveness is heightened if these characteristics are present in a school. This chapter presents the theoretical foundations as an orientation to the research, reviews the current literature of effective schools, and presents a critical review of that literature. Recent theories of organizational change and implementation are examined as a vehicle for implementing effective school characteristics in the school setting. Finally, a portrait of an effective school is presented. The case study of the RISE Project in Milwaukie is presented as an example of an effective school.

\section{Theoretical Foundations}

The effective school literature challenges previous research that had found unequal. academic achevement to be primarily a function of family background and related variables (Coleman, 1966: Jencks, et. al., 1972). 
Social scientists and opinionmakers continue to espouse the belief that family background is the chief cause for the quality of pupil performance. Such a belief has the effect of absolving educators of their professional responsibility to be instructionally effective (Edmonds, 1979).

Early researchers on effective schools, Coleman (1966), concluded that achievement by poor, multicultural children derived principally from inherent disabilities that characterized the poor from multicultural groups. Weber (in his New York study, 1971), Madden (in his California study, 1976) and Brookover and Lezotte (in their Michigan study, 1979) found evidence that de-emphasized the limits of family background of students as a variable for a successful school.

An effective school, as defined by Edmonds, Weber, Madden, Brookover and Lezotte, is a school

that effectively brings the children of the poor to those minimal masteries of basic school skills that now describe minimally successful pupil performance for the children of the midale class (Edmonds, 1979, p. 15).

Also, easily measured differences such as class size, teacher salaries, number of books in the library, the reading series, and the age of the building were found to bear little relationship to achievement (Averich, 1972; Jencks, 1972; Murnane, 1980). 
Recent studies on the determinants of achievement have been concerned with variables relating to (1) how schools and school districts are structured and make decisions (2) the process of change in schools and school districts, and (3) the way in which classrooms and schools can increase the amount of time spent on productive instruction (Purkey, 1982).

The major strategy of school effectiveness research has been to statistically determine highly effective schools by analyzing math and reading achievement scores. These studies employ regression analysis of school mean achievement scores, controlling the student body socioeconomic factors. Based on the regression equation, an expected mean achievement score is calculated for each school. The expected score is subtracted from the actual achievement level of the school to give a residual score. The researcher then selects the most positive and the most negative residual scores and labels the schools they represent as effective or ineffective.

\section{Current School Effectiveness}

The current approach to effective school research began in the state of New York, carried out by the New York State Department of Education (1974). In his studies Weber (1971) found that leadership, expectation, and 
atmosphere had an effect on reading achievement. A team approach to setting goals, teachers who believe in their power to teach and the ability of their students to learn, and an orderly, purposeful atmosphere characterize the achieving school. Although this preliminary study did not identify all of the factors that are related to student reading achievement, the findings were consistent with a significant body of other research.

Madden, Lawson, and Sweet (1976) studied school effectiveness in California. Twenty-one pairs of California elementary schools, matched on the basis of pupil characteristics and differing only on the basis of pupil performance on standardized achievement measures, were studied. The research attempted to identify those irstitutional characteristics that seemed most responsible for the achievement differences that described the twenty-one high-achieving schools and the twenty-one low-achieving schools. The major discoveries for the high-achieving schools were:

1. Principals provided teachers with support;

2. Teachers were task-oriented and applied appropriate principles af learning;

3. Teachers monitored students' work;

4. Teachers spent a great amount of time on langauge development, social studies, and science; 
5. Large numbers of adult volunteers helped in classrooms ;

6. Teachers had access to outside the classroom materials;

7. Faculty felt they had little influence on educational decisions;

8. Teachers rated their administration highly;

9. Teachers divided classrooms into only few groups for instruction infrequently; and

10. Teachers were satisfied with various aspects of their work.

This California study is notable chiefly for its reinforcement of leadership, expectation, atmosphere, and instructional emphasis as consistently essential institutional determinants of pupil performance.

In 1977, the Michigan Department of Education asked Brookover and Lezotte to study a set of Michigan schools characterized by consistent pupil performance improvement or decline. The Brookover and Lezotte study (1977) was broader in scope than the two earlier studies. As determined by criterion-referenced standardized measures of pupil performance in basic school skills, Brookover and Lezotte chose eight schools to be studied (six improving, two declining). Brookover concentrated on six clusters of variables generally thought to influence school performance: 1) leadership, 2) personnel, 3) finance, 
4) curriculum and instruction resources, 5) facilities and 6) community. School success was defined as positive changes in any one or a combination of the following variables: (1) student achievement, (2) student attitudes toward school or themselves as learners, and (3) teacher attitudes toward the school or students as learners. Brookover, (1978) in his final report gave this summary of results:

1. Improving schools staff placed more emphasis on accomplishment of the basic reading and math objectives;

2. Improving schools staffs tended to believe that all of their students can master the basic objectives and believe that ability levels are high;

3. Improving schools staffs held higher expectations for the amount of years students would spend in school;

4. Teachers in improving schools accepted the responsibility to teach basic skills while declining school staffs felt they could not influence achievement and did not spend much time teaching basic skills;

5. Declining schools spent less time teaching reading and math because they felt they couldn't influence growth; 
6. In the improving schools, the principal is likely to be an instructional leader and assumes responsibility for evaluation of the achievement of basic objectives; declining school principals were interested in informal collegial relationships with teachers;

7. Improving school staffs show greater degree of acceptance of the concept of accountability;

8. Generally, teachers in the improving school are less satisfied than the staffs in the declining school. Declining schools seem to reflect a pattern of complacency and satisfaction with current levels of educational attainment;

9. Improving schools have a high level of parentinitiated involvement; and

10. Improving staffs are characterized by a greater use of paraprofessional staff. (Brookover, 1978 p. 317)

In 1979, Edmonds and Frederiksen conducted the "Search for Effective Schools" in Detroit's Model Cities Neighborhood. Their thesis was that "all children are eminently educable and that the behavior of the school is critical in determining the quality of that education" (Edmonds, 1979). Using the Sanford Achievement Test and the Iowa Test of Basic Skills, they selected two schools: Duffield and Bunche. The Duffield schools averaged nearly 
four months above the city average in reading and math and the Bunche pupils averaged nearly three months below the city reading average and 1.5 months below the city math average. They found substantive differences between the high achieving school and the low achieving school in the areas of 1) time spent on instruction; 2) commitment to (and assumed responsibility for) student achievement; 3) use of competitive team games in instruction; 4) expectations for student achievement; 5) ability grouping procedures; 6) use of appropriate reinforcement practices, and 7) the leadership role of the principal. In summary Edmonds described an effective school as one "characterized by high evaluations of students, high expectations, high norms of achievement, with appropriate patterns of reinforcement and instruction," in which students "acquire a sense of control over their environment and overcome the feeling of futility which ....characterize the students in many schools" (p. 243).

1. Teachers make a difference; certain teachers can have greater success;

2. Effective teachers focus on academic goals;

3. Effective teachers promote extensive content coverage and high levels of student involvement;

4. Effective teachers select instructional goals and materials and actively monitor student progress; 
5. Effective teachers structure learning activities and include immediate, academically oriented feedback; and

6. Effective teachers create an environment that is task oriented but relaxed (Edmonds, 1979).

Averich (1972) studied classroom organization and the specifics involved in organization and management and how these are related to instruction. The results from the study strongly support two generalizations: (1) classroom organization and management skills are intimately related to instruction, and (2) good instructors tend to be good managers (good organization management is good instruction).

The best known summarization of all of the effective schools literature was provided by Edmonds (1979), based on his own work and that of other researchers such as Weber (1977), Averich et al. (1972), Brophy and Good (1970), and Brookover (1977), Edmonds 1isted five ingredients of an effective school:

strong administrative ieadership, high expectations for children's achievement, an orderly atmosphere conducive to learning, an emphasis on basic skill acquisition, and frequent monitoring of pupil progress. (pp. 15-17)

\section{Limitations of Effective School Literature}

Edmonds' (1979) research findings are criticized by some researchers. Scott (1979) wrote that effective 
learning is a three-legged stool. The student as an individual, the school, and the home make up the legs of the stool; it is as strong as its weakest leg. Edmonds' theory is backed up by only two colleagues (Weber, 1971, and Brookover, 1979). Edmonds ignores evidence reported by white (1975), which found only one of twenty-five instructional practices significantly related to environment. However, thirteen significant correlations were obtained between achievement and home environment factors, thus indicating that home environment is an important variable in a student's achievement.

Edmonds' case for school-based learning depends on the Detroit and Equal Educational Opportunity Survey reanalysis studies that he conducted. He identified an effective school as one above the city average grade equivalent in math and reading, and an ineffective school was defined as below the city average. Predictably, in some schools, performance fell in some areas above while performance in other areas fell below the average. However, this finding scarcely warrants the assumption that some of the schools were indeed outstandingly effective or ineffective, or that home influences do not significantly influence student learning. Edmonds' investigation into teaching effectiveness included comparisons between two schools, Duffield and Bunche. Edmonds matched the two schools because of similarities in class size and years of 
teacher experience but did not look at kindergarten or first grade I.Q. test results. He concluded that because the schools were from the same socio-economic areas there was no difference between the schools. However, achievement scores of two schools did differ significantly. The differences could be traced to inter-school differences such as lower proportion of students qualifying for state compensatory education, student mobility, or fewer pupils overage in grades three through six (22 percent vs. 51 percent).

In his reanalysis of EEOS data, co-authored with Fredericksen (1979), Edmonds stratified pupils by race and responses to nine questionnaire items asking if their family had a television set, telephone, record player, hi-fi, or stereo, refrigerator, dictionary, encyclopedia, automobile, vacuum cleaner, and newspaper. The resulting data revealed that even the nine home items are consistently related to test scores. Both Black and White pupils with more home items achieved higher test scores. Thus Edmond's own analysis contradicts his main point that family background has no influence on achievement. Purkey and Smith (1982) criticized the effective school literature in their paper "Effective Schools-A Review." They were critical of the assumption that the effective school variables can be reduced to five or six variables. They cite many different studies that have 
have tested the same variables and their findings tend to negate each other.

For, example, the first New York study (1974a) found that methods of reading instruction varied greatly between high and low performing schools. A follow-up study (1974b) found the opposite-method of reading instruction did not appear to make any difference. A third New York study (1976) again found differences in classroom instruction, although it did not highlight the same instructional features as the first study. The Maryland study concluded that effective schools are characterized by strong instructional leadership, while spartz (1977) found that effective schools have principals who emphasized administrative activities ( $p .7$ ).

Each researcher has found a different number of variables that are related to achievement. Spartz (1977) found seven, Brookover and Schneider (1975) identified six. Brookover does not mention ability grouping while the Delaware and two New York studies consider this a significant feature. Finally, Purkey and Smith (1982) stated, after a review of the Lezotte et al. (1977) study of model cities schools, that they were unable to identify the critical factors that others attributed to Lezotte to support their own findings.

Purkey and Smith (1982) presented five other limitations of the effective schools research. First, they said that "narrow and relatively small samples were used for intensive study" (p. 8). They maintained that most of the case studies involved two to twelve schools. The 
small sample greatly increases the possibility that the characteristics which appear to discriminate between high and low achieving schools are chance events. The small sample size raises other questions about the representativeness of the samples and the generality of the results from any one study. For example, these studies were completed in urban, low income areas and on that basis claims of what might constitute an effective program for other populations can not be considered certain. Another weakness of the effective school research was that many studies failed to utilize strong measures to partial out the effects of social class and home background. Purkey and Smith (1982) believe that in many studies the measures used to partial out social class and home back ground were weak and inappropriate. Thus, in the studies, the differences between high and low achieving schools were confounded with student background differences. They believe that the New York (1976) study that compared 148 positive schools with 145 negative schools contains conclusions that are meaningless because of this problem.

Another criticism leveled at the research on effective schools is that most of the studies have aggregated achievement scores at the school level. Purkey and Smith 
(1982) said that none of the studies looked at the achievement levels of different sets of students within the schools. Rutter (1979) found that exemplary schools were equally effective with different subgroups with the school. Edmonds and Frederiksen (1979) reanalyzed parts of the Coleman et al. (1966) data and found that in some schools different groups of students responded differently to certain school characteristics.

Hall \& Alfred (1976) have pointed out that comparisons of negative schools with positive schools may be inappropriate. They recommend comparing positive schools with average schools rather than negative schools. Purkey and Smith (1982) agree that comparing an effective school which falls at the positive end of the spectrum and a negative school that falls at the negative end is not the best comparison.

If negative residuals are pathological in some way so are in their own way, positive residuals.... The important differences between effective schools and average school may be very different from the differences between ineffective and effective schools. Unless schools are capable of making quantum leaps in effectiveness it will probably not profit a very poor school to compare itself to an exceptionally good school (p. 10).

The fifth limitation of effective school research, as cited by Purkey and Smith (1982), is the use of subjective criteria for determining school success. Finding a statistically unusual school does not necessarily mean it 
is "unusually effective" since effectiveness "depends on one's subjective scale of magnitude" (Hall 1975, p. 54). An "unusually effective" school in a predominantly low-income area might have considerably lower achievement than a middie class white suburban school.

For example, the effective school described by Armor et al. (1976) had a median score of $31 \mathrm{com-}$ pared to the district median of 38. Two reasons for this are the pervasive influence of social class on achievement, and the possibility that even the "typical" suburban school has some significant and important advantages over the relatively effective inner city school. (Purkey and Smith 1982, p. 11)

Even though researchers point out the limitations of the effective schools research and caution those people who reduce the findings of the effective research to five or six variables, Purkey and Smith (1982) in a general critique of effective school research summarized by stating that there is an intuitive logic to the results of the research and there is consistency in the results. For example; better control or discipline and high staff expectations for student achievement show up as critical factors in four of the seven studies for which there is data. Common sense would dictate that an orderly atmosphere would be conducive to learning and that emphasis on basic skills acquisition and frequent monitoring of pupil progress would tend to establish a more effective instructional program. An emphasis on instructional leadership 
by the principal was found to be important in three studies. Purkey and Smith (1982) said that the current research on effective schools is not useless or irrelevant and they advise. school personnel to read the current literature if they want to improve their schools. They caution that the adoption of the characteristics suggested by effective school literature is a complex process and has to be individualized for each school.

\section{The School As an Organization}

The lists of effective school characteristics compiled by researches and reviewers are helpful because they give direction to elementary schools. If the culmination of these effective characteristics does impact on pupil achievement, then all elementary schools should attempt to implement them. Purkey and Smith (1982) caution that administrators realize that they cannot simply use these characteristics as a recipe for an effective school. Information on school organization and how it relates to decision-making and implementation of innovation should be recognized.

The literature indicates that a student's chance for success in learning cognitive skills is heavily influenced by the climate of the school (Brookover et al., 1979). A school level culture that gives emphasis in the 
direction of academic achievement helps shape the environment (climate) in which the student learns. An academically effective school would be likely to have clear goals related to student achievement, teachers and parents with high expectations and a structure that would maximize the students opportunities to learn. A school that emphasized high academic success is more likely to reach that goal than a school that emphasizes social development.

In order to change the climate of a school, it is necessary to view the school as if it were a culture (Rutter, 1981; and Brookover, 1979). Each school has its own culture formulated by people's attitudes and values in the school. Each school has a sub-culture that interacts to make up the whole school culture. In order for change to occur in this environment, the attitudes and values have to change. Therefore, the interconnectedness of the school culture conceptualization directs attention to the process by which a given school climate comes into being and is maintained. Components that go to make up a school exist in a delicate balance. Intervention in any dimension puts pressure on the others and affects the equilibrium (Derr and Deal 1979). Therefore, school improvement is more likely to be successful if the whole school is treated, with special attention paid to people's attitudes (Rutter 1981) and how people interface with the environment and with each other. 
Recent research has rejected a notion of schools as bureaucracies, hierarchically structured, and susceptible to control with a high responsiveness at the lowest level (the classroom) to the goals set by the administration. Weick (1976); and March and Olsen (1976) view schools as "loosely coupled systems" in which the work of the teachers is largely independent of the principal's immediate supervision. Classrooms are isolated workplaces subject to little organizational control (Meyers and Rowan 1978) where teaching and learning are relatively free of evaluation (Dornbush and Scott, 1975).

If schools are "loosely coupled" in the above sense, then attempts to increase their effectiveness through mandated policies are unlikely to work. The various groups in the school that make up the school's culture may not agree with the principal or with each other; as a result, obtaining and maintaining a united school goal is difficult.

If a school is to change, then the peoples' attitudes and behaviors have to change, as well as school organization and norms. To produce this end, consensus among the staff of a school is more powerful than overt control, without ignoring the need for leadership. Building consensus around specified norms and goals is a key element in a school's improvement strategy. Popkewitz, in the Journal of Education (1981), added a different 
dimension by stating that reform in an organization is a way of stabilizing the kind of school that already exists. In other words, change masks the status quo of a school organization. He believes school environments fall into three categories: (1) "Technical" (those schools that emphasize recording data, test results etc), (2) "Constructive" (those schools that are student oriented, consensus decision making) and (3) "Illusory" (schools where teachers feel they are teaching low students that cannot learn so they actually do not spend much time teaching; their rationale is that they want to make school fun). (p. 5)

\section{Theory of Change}

Whatever the school environment, culture, or image, change will look different in each school, as the people adopt and interpret the change. Research claims that change means that peoples' ways must be changed. This philosophy is stated by Lieberman and Miller (1981). They wrote that, in order for change to be successful, the culture has to change, and the change has to be linked with real concerns of the people involved.

When change is successful it is because schools are approached as cultural entities. Change is seen as developmental, linked to teacher concerns, and fostered (not mandated) by leadership which recognizes the importance of concrete and symbolic support of teachers and the motivating force of a teacher's sense of efficacy in the classroom (pp. 583-586). 
Change tends to re-establish credibility for a formal organization. Change is the interface between the community and the schools and gives the image of efficacy, effectiveness, and responsiveness to problems. This is one reason change is viewed as positive. However, Gross (1971) wrote that "a decision to change is only a proposal to change" (p. 214). Hansen (1979) stated that there are many outcomes of change that describe the degree of change that has been made. He said "mutual adaptation" refers to an innovation that has changed as well as the people who are involved in the change. The people and innovation adapt and the change is incorporated. "Non-implementation' refers to no change in the innovation of the people. "Cooptation" occurs when the participants are indifferent and resist the change and the change is incorporated into the system anyway. This results in a one-way process where the participants do not practice the change. This is also a "symbolic adaptation." "Diffusion"refers to the spread of the innovation to the people involved. (p. 335)

\section{Change Models}

Change can be planned (through a systematic process), spontaneous (as a reaction to an immediate problem), or evolutionary (where the change takes a long time to implement). An evolutionary change goes through many changes or stages, as with conforming to handicap laws. 
Hansen (1979) wrote that a change occurs because of a change force. This force can be technical knowledge, people motivation, new laws, politics or economic reasons. He stated that innovation and change are carried out by any one of three models. In the "managerial model," the administration or central office makes the decision to change. In the "learning model," people are involved with problem solving. In the "bargaining model," the administration and teachers bargain and negotiate each step of the change.

Hansen (1979, p. 305) provides the following model of change:

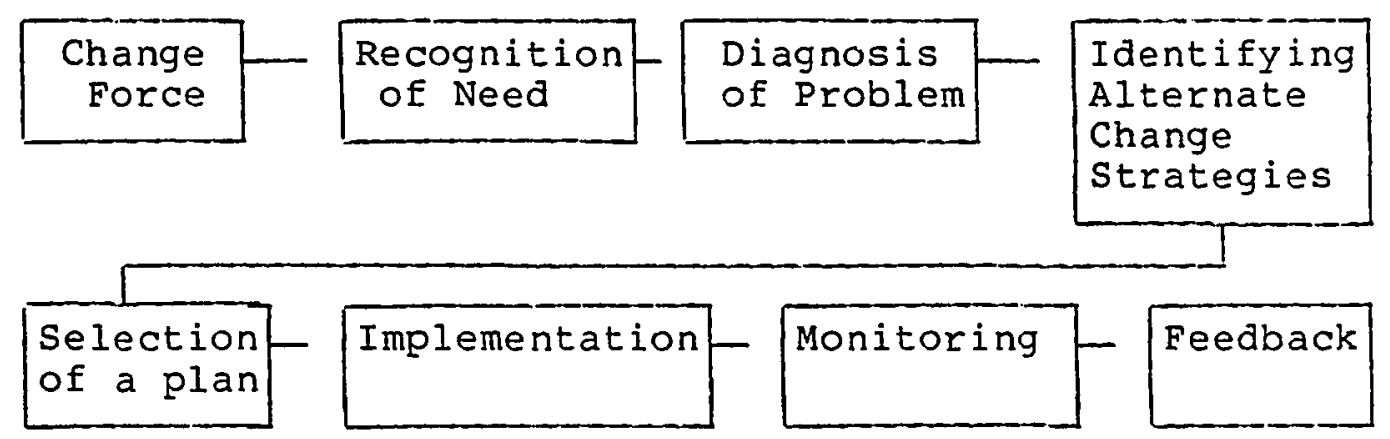

When an organization has gone through the eight steps of change the steps are repeated since the last stage feedback will produce ideas or suggestions to modify the change. The process is repeated so that the modifications can be implemented. 
The federal government has spent millions of dollars trying to learn if federal money given to schools to implement programs has resulted in actual change. The model the federal government used to incorporate change was the Research, Development, Diffusion and Adoption model (RDDA). This model assumed that the people in the organization wanted the change. The federal government found that generally the RDDA model resulted in cooptation of the innovation, where the innovation was incorporated into the system but the people did not change their behavior or accept the change. The failure of this model was due to the fact that it did not consider the people who were to be involved in the innovation. The Configuration model was developed after the RDDA model, and it provided for involvement of the participants in the innovation (Lewis, et al. 1980).

Hall and Alfred (1976) clarify that a successful "Innovative Process" consists of three parts:

1. Initiation: (felt need is important as well as people involved having a say in the decision process),

2. Implementation: (assistance in the classroom is important, a consultant to help as well as administration support provides assistance, linkage and incentives), 
3. Incorporation: (It is necessary to evaluate and find success).

Havelock, in The Change Agents Guide (pp. 13-14), gives some light as to how this innovative process can take place with the help of a linking agent. This agent helps the user define the problem and solve the problem, and helps in search and retrieval and with applicaion. The linking agent is aiming for what Hansen (1979) calls "essential change" where the change is voluntary. The key factor in a voluntary change is that the people feel a need and want to change. Guba (1974) wrote that people can be convinced of a need by several techniques: (1) appealing to their values (it will be good for kids), (2) rationale (it will be good for the school), (3) didactic (not trained for the change but will be trained), (4) psychological (people having a say in the innovation), (5) economics (rewards), (6) politically (influenced to change) and (6) authority (compelled to change).

\section{Resistance To Change}

Many times change will appear to be accepted by the participants involved until the innovation gets to the implementation level. This is where resistance occurs. Hansen (1979) wrote that resistance comes from two sources: (1) from the make up of the organization and (2) 
from the people in the organization. He discussed road blocks to organizational change. The fact that education is a national system, linked through tests, textbooks, court decisions, and the National Education Association, makes it hard to change since one small change means the whole system has to change. He stated that, because education is bureaucratic, the change process is complicated, with too many people involved. Educators have what Hansen calls "goal misplacement," which means that many people in education believe that the goal should be to follow the rules and not to get into trouble. This insecurity breeds rigidity. The educational system is also domesticated. There is little pressure to perform as there is in business. Education is made up of functional equivalents. If one part is taken away another one is put in its place. Finally, the cost and time involved in implementing a change might not measure up to the unknown outcome. It might not be worth the effort. The National Diffuson Network's (Hall, Alford et al., 1976) evaluation of the federal change projects added to Hansen's list of reasons for resistance to change. They maintained that goal ambiguity, too many input variables from inside and outside the system, role performance invisibility, low interdependence, and absence of a change agent all tended to inhibit organizational change. 
Pickhardt (1979), in The American School Board Journal p. 10, suggests that a Burt Lance mentality of, "If it ain't broke don't fix it" is an attitude that is found in educational organizations. Pickhardt wrote that change is not always good or for the better. Beware of innovations, he warns. They might be fads. Lieberman (1980) wrote that districts are too worried about getting federal money and not worried enough about the needed change. Districts will tend to apply for money to make changes that the federal government wants to initiate so that the district will be awarded the money. This can further explain why innovations do not work. Miles (1964) said that outcome vagueness, weak incentives, weak professionalism, and vulnerability of the system are also reasons why innovations fail.

Hanson (1979) wrote that resistance al'so comes at the individual level. He said that people do not want to change because they might lose status or that their informal social groups within the system might be disturbed. Mobility is also a factor. If a person is upward mobile, he/she is more open to change. A person not upwardly mobile is not motivated to change. Teachers do not have a very high search behavior; psychologically they do not want to change. They have a lack of experimental ethic, they are afraid to fail, and they are not risk 
takers. There is very little incentive for change, considering the effort it takes to implement a change.

Goodlad (1983), in discussions of resistance to change, stated that morale influences a person's ability to change. Are the people involved in self-renewal which is determined by the communication set up by the principal? Goodlad continued that the locus of control is important. Do the people feel that internally they have control over their lives and what happens around them or do they feel that external factors control what happens? Goodlad also wrote that some indicators of a person's ability to change reside in job satisfaction, interest and participation in out-of-town education meetings, and in general, the varied experience outside the school. Blau (1976) wrote that if people feel secure and if they feel they have mastered their job, they will want to change as it will be an added challenge.

More research that attempts to give reasons why there is resistance to change in organization includes the Rand Corporation findings that indicate that the age of a teacher is an indicator of whether he/she will adapt to change. The older the teacher, the more reluctant to change. The research determined that older teachers form outside interests that become more important than improving their professional position. 
Firestone (1980) stated that teachers have a lack of knowledge and have no system to share any knowledge. They are left in their classrooms to implement curriculum in any way they want. He wrote that, if they resist change, they will do it by non-compliance. They will be absent, or they will openly confront authority, or they will be passive and not implement the change.

Teachers' resistance is not a political act. They are just trying to preserve their private space, which they value.

Teacher come from a Iimited knowledge base (Lortie, 1975). They have very little collegial power and their professionalism is low. Lewin (1951) wrote that the best teacher incentive is a heightened feeling of professionalism, added resources, more status, sharing and added responsibility.

In order for resistance to change to be better understood Hersey and Blanchard (1969, p. 59) charted the levels of change, beginning with an individual's knowledge of the need for change and leading to the organization's changed behavior. 
Hersey and Blanchard (1979, p. 59) Levels of Change

\begin{tabular}{|l|}
\hline organization's behavior \\
\hline person's behavior \\
\hline person's attitude \\
\hline $\begin{array}{l}\text { knowledge } \\
\text { of change } \\
\text { issues }\end{array}$ \\
\hline
\end{tabular}

If a person is knowledgeable of the change and as a result of that knowledge changes his/her attitude, then the behavior will change and the end result will be a change in the whole organization.

Hall and Loucks, (1975) stated that people first have to internalize the change, (it has to become like an old sneaker), then they have to conceptualize the change (what it will look like in their lives), then they have to value the change, and if they have gone through these steps, they will respond to the change. Most resistance comes at the value level; if they do not value the change, they will not use it.

\section{Change Agents}

In order for change to take place, there has to be a change agent. The change agent may serve as a catalyst, a solution giver, a process helper, or a resource linker. 
Hanson (1979) wrote that the "White Hat" change agent causes change to happen through consensus. The "Machiavellian" change agent is political and that influences his style. The "Hatchetman" is usually sent to make quick change without people's input. The "Guerrilla" change agent is a person from within the system that establishes small groups of support. He/she moves quietly and does not usually have an official title.

The main goal of a change agent should be to maintain the present system and to change it to perform better (Havelock, 1973) Havelock maintains that the change agent first has to establish a trust relationship with the people involved. Research shows that people will resist change if they do not like the person who suggests the change. The change agent then has to help diagnose, provide resources, help with solutions, help get acceptance from the community and district, and help stabilize the innovation.

Research on effective schools claims that the principal in a school should be the instructional leader, which means he/she should enable change to occur. A survey of effective school research literature indicates that these variables are important for an instructional leader or change agent to practice: (1) strong leadership, (2) high expectations, (3) high task orientation, (4) involve- 
ment in instruction, (5) assertiveness, (6) close monitoring of progress, (7) high degree of structure, (8) clear mission for the school, and (9) leadership style directive or participatory depending on the situation. (Purkey and Smith, 1982)

\section{Implementation of Change}

Given a strong change agent, implementation of change involves a number of stages or levels, as defined by researchers. Hall and Loucks (1975), described the levels an innovation can go through:

1. No use;

2. Orientation (people become aware);

3. Preparation (people prepare to use);

4. Mechanical use (people use but is not refined);

5. Routine (people use but there is no attempt to revise and make better);

6. Refinement (people revise change so that it is more effective for the user);

7. Integration (people practices innovation changing as they proceed);

8. Revising (people talk with each other to make the whole program better); and

9. Renewal (the old program is revised and put into effect). (pp. 52-56) 
The change agent is the person who can make sure that the innovation goes beyond the routine stage. This can be done through intervention into the classroom, as a part of the inservice model which may include classroom assistance. Joyce and Showers (1980) offered a number of training components that are a part of an effective inservice program. These components are:

1. Presentation of theory or describing of skill or strategy ;

2. Modeling or demonstration of skills or models of teaching;

3. Practice in simulated and classroom settings;

4. Structured and open-ended feedback: provision of information about performance; and

5. Coaching for application: hands-on, in classroom assistance with the transfer of skills and strategies to the classroom. (p. 380)

Joyce and Showers reported that, singly and in combinations, each of the above components contributes to the effect of a training sequence or activity, but when used together, they have greater impact (p. 380). The coaching for application step and the structured and open-ended feedback step are often left out of an inservice plan. It is for this reason that many innovations that are presented in training programs do not result in changed teacher behavior in the classroom. 
If consistent feedback is provided with classroom practice, a good many, but not all, will transfer their skills to the teaching situation. For many others, however, direct coaching on how to apply the new skills and models appears to be necessary (Joyce and Showers, $1980 \mathrm{pp} \cdot 382-384$ ).

In order to accomplish school improvement through inservice training, all of the components must be used. If any one of the components is omitted, the impact of the training will be weakened in the sense that fewer numbers of people will progress to the transfer level. "The most effective training activities, then, will be those that combine theory, modeling, practice, feedback, and coaching to application" (Joyce and Showers, 1980, p. 384).

As an individual goes through an inservice activity, there are several levels of concern that occur within the individual. Those levels are:

1. Awareness (realizing there is a need);

2. Information (information as to how to solve the problem);

3. Personal Management (how will each individual manage the change);

4. Consequences (what will be the outcome after the innovation has been practiced);

5. Collaboration (talking with others to make the innovation better); and 
6. Reinforcement (how to make the innovation better). (Hall \& Loucks, 1978, p. 55)

An administrator who is aware of these levels of concern can insure that enough time is allowed during the implementation stages for an individual to progress through these levels. As people experience eaç level of concern and level of practice they sometimes get stuck on one level as the other members of the group move on to the next stages. This is why intervention and inservice on an individual base is effective. If assistance is given to the individual who has not advanced to the next stage on his/her own, then the end result will be that the whole group can reach the renewal stage together. The renewal stage is the final goal of any innovation, as it means that the change has been mutually adopted into the system. The renewal stage, where teachers communicate and revise the change, is important because research has shown that teachers learn best from each other (Goodlad, $1975)$

Purkey (1982) also suggested that staff development should be on an individual basis and related to the goals of the school that all participants have agreed upon. Berman, and McLaughlin (1977), in Federal Programs Supporting Change, Volume IV; The Findings in Re- 
view, wrote that there are four essential factors that need to be present for change to occur:

1. Institutional Motivation: (principal's commitment and how much the staff has a part in decision making)

2. Project Implementation: (staff needs to plan their own inservice, staff needs to have classroom assistance, clarity of final goal for the project)

3. Instructional Leadership: (there has to be district backing and the staff has to have a good working relationship with the change agent)

4. Teacher Characteristics: (factors that are important are attitude, ability, experience, their sense of efficacy, (i.e., how much control they believe they have over their teaching). Findings and conclusions from the Associates Study and Network, Inc. study of the early 1980's identified key ingredients in successful dissemination and diffusion of change to be:

1. Quick, visible results--most frequently in student achievement;

2. Involvement of the "critical mass" of teachers necessary;

3. Support and commitment from the school principal 
4. Successful innovations truly satisfying local needs and problems; and

5. Absolute necessity for local commitment of resources and energy (contrasted with "opportunism" for funds)

In summary, this study concluded that there is a need to shift focus of change efforts from system level to "classroom" level--allow teacher practice time and create "Iinkages" among teachers and administrators. The report ended with an optimistic view of the success of change efforts, i.e., teachers and principals can and do make a difference. Also, bringing about change does not take as long as the studies of the $70^{\prime} \mathrm{s}$ might indicate. (The A\&T Associates Study and Network, Inc., Study, 1980)

\section{Portrait of An Effective School}

The list of effective school characteristics compiled by researchers is helpful to the extent that they have captured those factors which are likely to have cumulative impact on pupils' achievement. Theories of school organization and literature on implementation and change give a process by which the effective school characteristics can be integrated into a school. Purkey and Smith (1982) combine the organization-structure characteristics of effective schools with the process-form variables and develop a portrait of an effective school. 
The framework or first group of characteristics in the portrait is comprised of organizational and structural variables which can be set into place by administrative and bureaucratic means. Purkey and Smith (1982) stated that the following variables are the most important organization-structure characteristics:

(1) School-site management. A number of studies indicate the need for a considerable amount of autonomy for each building in determining the exact means by which they address the problem of increasing academic performance. This flows from the emphasis on school-specific culture (Rutter 1979, 1981; Brookover et al. 1979).

(2) Leadership. Though we are suspicious of the 'Great Principal' theory, it seems clear that leadership is necessary to initiate and maintain the improvement process. (Weber 1971; Armor et al. 1976; Brookover and Lezotte 1979. The principal is uniquely positioned to fill this role and certainly his/her support is essential very early on, groups of teachers or other administrators can provide leadership. Staff-based leadership could more readily reduce teacher opposition to change, generate a greater sense of teacher "ownership" toward new methods, etc. More importantly, however, it seems likely to provide more stability and continuity. Successful principals seem to be promoted or transferred to other trouble spots while the staff remains more or less intact. Leadership from below may be more lasting as schools presently exist. Promoting leadership in a school is not a simple task. One strategy that a central administrator might use is to move into a school a proven leader-administrator. A second strategy is to introduce a process that requires that either the principal exert instructional leadership or that a teacher emerge as a leader.

(3) Staff stability. Once a school experiences success, keeping the staff together seems to maintain, and promote further, success New York State Department of Education 1974. Frequent transfers 
are detive and and likely to retard, if not prevent, the growth of a coherent and on-going school personality.

(4) Curriculum articulation and organization. At the elementary level if students are expected to acquire basic and complex skills, the curriculum must focus on these skills (Weber 1971; Armor et al. 1976; they must receive sufficient time for instruction in those skills (Fisher et al 1980), and those skills must be coordinated across grade levels (Levine and Stark 1981) and pervade the entire curriculum.

(5) Staff development. Essential change involves altering people's attitudes and behaviors as well as providing them with new skills and techniques. In order to influence an entire school the staff development should be school-wide rather than specific to individual teachers and should be closely related to the instructional program of the school (Venezky and Winfield 1979; Armor et al. 1976; Levine and Stark 1981). This effort is incremental and requires long-term support and reinforcment (Armor et al. 1976). More appropriately staff development should flow from the expressed needs of teachers revealed as part of the process of collaborative planning and collegial relationships.

(6) Parental involvement and support. It is reasonable to assume that parents need to be informed of school goals and student responsibilities especially with regard to homework. A few studies find parental involvement and support to be a major factor in student achievement (New York State Department of Education 1974; Armor et al. 1976; Coleman et al. (1981); Levine and Stark (1981). obtaining parental support is likely to postively influence student achievement.

(7) School-wide recognition of academic success. A school's culture is partially reflected in its ceremonies, its symbols, and the accomplishments it chooses to officially recognize. Schools which make a point of publicly honoring academic achievement and stressing its importance through the appropriate use of symbols, ceremonies and the like encourage students to adopt similar norms and 
Lezotte 1977; Coleman 1966).

(8) Maximized learning time. If schools choose to emphasize academics, then a greater portion of the school day would be devoted to academic subjects (Coleman 1981), a greater portion of the class period would engage students in active learning activities (Fisher et al. 1980; Brookover et al. 1979), and class periods would be free from interruptions by the loudspeaker, messages from the counseling office, or disruptions from the hall or yard outside (Fisher et al. 1980). Staff training might well be in the areas of classroom management and direct instruction. (Purkey and Smith 1982)

(9) District support. Fundamental change, building-level mangement, staff stability, etc. all depend upon support from the district office. Few, if any, of the variables found to be significant are likely to be realized withut district support. (Hersh et al. 1981. While specialized help in some areas such as reading or mainstreaming seems helpful (Hargrove et al. 1981), the role of the district office is probably best conceived as guiding and helping. Hostile, perhaps even indifferent, attitudes by the district office toward school improvement programs reduce the likelihood of their being successful (pp. 37-39).

These nine organization-structure factors set the stage for the process-form variables. The process-form variables have to do with climate and culture of the school. They are the characteristics that the innovation and change research indicates need to grow organically in a school and are not directly susceptible to bureaucratic manipulation. Purkey and Smith (1982) wrote that the characteristics of a productive school culture seem to: 
(1) Collaborative planning and collegial relationships. (Little 1981; Deal et al. 1977). Directly concerned with process, this variable comes both from school effectiveness research and from implementation research which suggests that change attempts are more successful when teachers and administrators work together. Collegiality serves many purposes. Chief among them are that it breaks down barriers between departments and among teachers/administrators, it encourages the $k$ ind of intellectual sharing that can lead to consensus, and it promotes feelings of unity and commonality among the staff.

(2) Sense of community. (Newmann 1981). There is persuasive evidence that community feeling, the sense of being a recognizable member of a supportive and clearly perceived (by the staff and others) community, contributes to reduced alientation and increased achievement. There is also evidence that schools can create or build community by the appropriate use of ceremony, symbols, rules (i.e., dress code), and the like.

(3) Clear goals and high expectations commonly shared. (Brookover et al. 1979; Brookover and Schneider 1975; Armor et al. 1975; Venezky and Winfield 1979; New York State Department of Education 1974, 1976; Weber 1971). Common sense, if nothing else, indicates that a clearly defined purpose is necessary for any endeavor hoping of success. Within the limits imposed by the common public school philosophy, schools need to focus on those tasks they deem most important. This allows the school to direct its resources and shape its functioning toward the realization of those goals. Continual monitoring of individual pupil and classroom progress is a logical means of determining if the school's goals are being realized and can serve to stimulate and direct staff energy and attention (Levine and Stark 1981; see also Edmonds 1981). Newmann (1981) suggests that having clearly defined and limited goals would reduce student alientation, an all too common barrier to increased effectiveness in any area of schooling. Academically successful schools are also characterized by the expectations of the staff and students. In all cases these expectations were for work and achievement. 
Finally, schools that reach consensus on their goals and expectations are more likely to be successful--in a sense they have channeled their energy and efforts toward a mutually agreed upon purpose.

(4) Order and discipline. (Brookover et al. 1979; Weber 1971; Armor et al. 1976; New York State Department of Education 1974, Edmonds 1979, 1981). The seriousness and purposefulness with which the school approaches its task is communicated by the order and discipline it maintains in its building. Again, common sense alone suggests that students cannot learn in an environment that is noisy, distracting or unsafe. Furthermore, some evidence exists indicating that clear, reasonable rules, fairly and consistently enforced, not only can reduce behavior problems that interfere wth learning but also can promote feelings of pride and responsibility in the school community ( $\mathrm{pp} .37-39$ ).

Purkey and Smith (1982) summarize their list of process-learning variables and organization-structure variables by stating that these variables are intertwined with each other and both types of variables have to be present in a school if there is to be an increase in student achievement made possible through innovative changes.

\section{Case Study of An Effective School}

Given Purkey and Smith's (1982) portrait of an effective school, it is possible to identify a school that can be determined to be effective because it is practicing the organizational and process variables that are common in effective schools. The Milwaukee's Project RISE, which 
involved twenty Milwaukie schools, closely parallels

Purkey and Smith's portrait of an effective school.

Schools in the RISE project were selected because of low scores, and their student bodies had a large percentage of low-income and minority students (McCormack, Kritek, 1982). Many of Purkey and Smith's processlearning variables were put into place. A strong sense of academic mission was developed by emphasizing the need for basic skills. Issues related to instruction and curriculum dominated most staff meetings, and there was an emphasized effort for staff members to reach consensus in establishing the school's philosophy, goals, and policies. Grade level meetings were held frequently to determine strategies for teaching math and reading. Reading, Math, and Language Committees were formed to provide a forum for discussion and determination of the schools' policies.

The development of a strong sense of student identification and affiliation with the school was established. Efforts to create an atmosphere of support and belonging included school honor assemblies, the use of school logos printed on T-shirts and on buttons, and student council.

Grade level expectations and standards in the areas of reading, math, and language were established. Teachers used these expectations as a guide in their planning and 
students and parents were informed of the checklist of standards.

Some of the organizations-structure variables (Purkey and Smith, 1982) were put into effect. An accelerated learning program for students performing well below grade level was developed. One component of the accelerated learning program was whole class instruction at grade level supplemented by small group instruction at the student's actual skill levels.

The amount of time allocated and actually used for the teaching of reading and math skills was increased. Each school implemented and enforced a school wide homework policy. Inservice training provided techniques for developing a structured learning environment. Techniques of direct instruction provided a sequenced instructional pattern, and clearly defined behavioral expectations contributed to orderly task oriented classrooms.

The results for the RISE Project were analyzed by comparing the Achievement tests results from 1975-76 to those of 1980-81. Direct evidence of improved achievement for the RISE Project was discovered. For example, the average percentage of RISE fifth graders(unweighted mean of individual school percentages) in the lowest category of reading performance was 408 in 1982, down from 55 to 1979; the comparable figures for fifth grade math were 21\%. Some schools made gains greater than the average, 
and others showed only moderate gains or no gains at all. About half of the sixth, seventh, and eighth graders at RISE schools are still in the lowest performance categories in vocabulary and reading comprehension (the national figure is $23 \%$ ); more than $40 \%$ of the third, fourth, and fifth graders still score in these low categories. The RISE evaluators believe that there is still much to be done. However, they are encourged about the gains that have been made so far. (McCormack, Kritek, 1982)

\section{Summary of the Literature Review}

Effective school research is oftentimes presented as a simplistic recipe for school improvement. However, the . review of the literature, especially that concerning change in schools, reveals that the task may be much more difficult than it first appears.

The basic findings of the effective schools research fall into a consistent pattern. Most schools with effective programs are characterized by high staff expectations and morale, a considerable degree of control by the staff over instructional and training decisions in the school, clear leadership from the principal, clear goals for the school, and a sense of order in the school.

Criticism of the research on effective school indictes that the case studies generally share five 
weakness: small and unrepresentative samples, possible errors in identifying effective school because of uncontrollable student body characteristics such as social class, achievement data aggregrated at the school level, inappropriate comparisons, and use of subjective criteria in determining school success.

Flaws in the original research do not conclusively discredit the characteristics determined to be effective in a school. Common sense would dictate that characteristics such as high expectations, orderly learning environment, high morale, clear goals, and instructional leadership would produce higher academic achievement and thus, an effective school.

successful implementation of these effective characteristics requires that theory on organizations and change be recognized and provided for in the initial planning stages. Organizational theory indicates that schools consist of individual "cultures," which refers to the nature and style of political-social relationships and the communication network that has been established within a school. These factors are unique to each school and provide for a definite school personality. If the school is to implement an innovation that will change the content (meaning the roles, norms or instructional techniques of a school), then the people in the school have to change. The research on change indicates that to achieve mutual 
adaptation of an innovation, a key factor is that decisions by consensus among the staff must be part of the implementation efforts. Change will not take place without support and commitment of the people who must come to "own" the new educational ideology and technique. (McLaughlin, 1978)

There are many change models that can be used to implement change. However, in order for these processes to reach the final step of renewal and accomplishment of goals, knowledge of the process an individual goes through to change during the change effort is also important. Change agents can foster successful change for an individual by providing feedback and classroom intervention as part of a training program.

Purkey and Smith (1982) suggest combining the organizational and instructional variables with the process variables to insure that the effective characteristics will result in an incorporated change for the system and for the individual teacher. They caution that for an organization to dictate the use of effective variables without providing for the individuals involved to take part in the process of implementation would result in failure of the innovation. 
CHAPTER III

RESEARCH DESIGN AND METHODOLOGY

Introduction

This study was designed to test these research expectations. (1) A year long Basic Skills program which uses materials that cover skills determined to be the lowest areas on the California Achievement Test and which implements certain characteristics of effective school, will result in improved NCE test scores in the low academic areas. (2) The relative position of students in the norming sample will change in a positive direction for those who have received the treatments to a greater extent than those who have not received the treatment. These effective school characteristics include (1) better control or discipline, (2) high staff expectations for student achievement, (3) instructional leadership by the principal, (4) a clear set of goals and emphasis for the school, (5) a school-wide effective staff training program and (6) a system for monitoring of student progress and significant growth in achievement test scores. This study compared achievement test results from the Spring of 1982 for grades four, five, and six (from 
Clackamas Elementary School, North Clackamas School District approximately 140 students), with the achievement test results for grades four, five and six from the spring of 1983. The control group took the California Achievement Test the year before the treatment group; during the Spring of 1981 they took the pretest and in the spring 1982 they took the posttest. The treatment group took the pretest in the Spring of 1982 and the posttest in the Spring of 1983 .

\section{Treatment Procedures}

In the spring of 1982 the teachers at Clackamas Elementary analyzed the achievement test NCE scores for grades four, five, and six. The teachers determined that the lowest areas were in reading and math. The weak areas in reading were comprehension, recall of facts, identifying fact and opinion, identifying main idea, and character analysis. The low areas in math were addition, subtraction, multiplication, and story problems.

A survey was given to the teachers to determine how they wanted to develop the program that would attempt to improve these weak skill areas. A committee analyzed the surveys and came up with a Basic Skills Program that was presented to the staff in May, 1982. The program began in the Fall, 1982, and continued until the students were tested again in the spring of 1983. An outline of the program appears in Appendix $B$. 
The Basic Skilis Program began with grades four, five and six taking the PRI (Prescriptive Reading Inventory Test) by McGraw Hill. The PRI was given to confirm the California Achievement Test results of the year before and to obtain a more distinct break-down of skills in reading. The results from the California Achievement Test indicated that students at Clackamas Elementary were low in the Reading areas of recall of facts, identifying fact and opinion, identifying main idea and character analysis. The PRI test broke these areas down further by testing the skills that make up the comprehension areas of the California Achievement test. For example, (1) recall of facts was broken down into the categories of story setting, story detail, event sequence, motivation, sentence paraphrasing, and paragraph paraphrasing; (2) identifying fact and opinion was broken down into drawing conclusions, metaphors, similes, and idioms; (3) identifying main idea was broken down into the categories of main idea, topic sentence, main idea summary, and passage summary; (4) character analysis had one test, character analysis. The PRI not only tested the low areas in a more complete way but also provided a kit that contained instructional materials, such as the worksheets teachers used to teach each subscale skill that had been identified as low. The test scores from the PRI were kept by each teacher so that improvement of a 
particular skill could be recorded when the child mastered the skill as the year progressed. The kit provided for strand tests that tested for mastery of individual skills. These strand tests were designed in the same format as the California Achievement Test that the students would be taking to measure their year's growth that next spring. The kit also provided several tutor sheets that would help teach each skill. The tutor sheets were used as homework papers that would further reinforce the skill to be learned. The kit also provided ideas and methods teachers used when teaching the concept to the whole class.

The PRI test results gave the teacher a precise record of each student's achievement in the area of reading comprehension and the different reading skills that make up that category, and provided them with materials to teach a particular skill. The Parkrose School District's Reading Materials were also used. Parkrose had developed an inventory of reading worksheets compiled from different reading programs over the years, and had categorized them into reading skills areas such as main idea, sequencing, character analysis, and other. The combination of these two sets of materials provided ten to fifteen worksheets for each reading skill.

The DMI (Diagnostic Math Inventory) by McGraw Hill provided practice sheets for the four math categories and 
strand tests, developed in the same format as the California Achievement Test to test if the skill had been mastered.

The implementation of some of the effective schools variables was accomplished by developing a calendar of six-week grade-level meetings (as seen in Appendix B). The effective school research emphasized the importance of the principal being an instructional leader and the importance of establishing clear academic goals for the school. The principal and vice principal coordinated the grade level meetings and thus were part of the instructional planning at each grade level. The purpose of the grade level meetings was to discuss the one goal in reading and math that would be covered by the teachers in the next six weeks. The teachers decided in what order the priority goals would be worked on and they then emphasized that skill for six weeks. For example, during the first six weeks all of the grade level feachers worked on addition and recall of facts with their students. At the end of the six weeks period, the grade levels met again and evaluated the results of the different strand tests that were used during the six weeks to test mastery of different subskills trat fell under recall of facts and additions. The worksheets that were used to teach recall of facts dealt with materials and strand test that covered story setting, story detail, event sequence, motivation, 
sentence paraphrasing, and paragraph paraphrasing. In the area of addition, there was only one grade level strand test that tested for mastery.

By recording and evaluating the results of the different strand tests, another effective school variable was incorporated into the program. Effective school research emphasizes the importance of a school having a system for the monitoring of students' progress. As the principal and vice principal helped teachers evaluate the results of the strand tests, it was decided whether the students needed more work on a specific skill or if they had mastered the skill and could go on to the next skill. The administration developed recording sheets (Appendix C) that were designed to help teachers record the results from the worksheets which they used to teach a skill and which also showed the pretest and posttest scores for that ski1l. These recording sheets had the names of the students printed on them so that the teacher could easily record data beside each name. On the recording sheet the teachers put a ( + ) mark indicating mastery, an ( $R$ ) mark indicating review the skill and $a(-)$ indicating the skill needed to be taught. This formula was developed by PRI as the method to use when grading strand tests. A score of a $(+)$ meant five to six right, a (R) meant three to four right and a (-) meant zero to two right. A sample of a teacher, completed recording sheet appears in Appendix D. 
After evaluating the results of the previous six weeks, PRI worksheets were selected that would teach the new skill, and the strand tests used to test mastery of those skills were handed out.

High expectations for student's achievement, another of the effective school variables, was another area the administration attempted to develop in the grade level meetings. Teachers were encouraged to develop certain high standards that they wanted their classes to meet when trying to improve the low skills. They were encouraged to re-teach areas where scores did not meet those determined standards.

The administration also set the goal of developing a homework policy for the school that would help establish the parents as partners who would help children achieve the high academic standards set by each teacher. This policy was established in January of the treatment year by consensus of the staff. A copy of the homework program can be found in Appendix $E$. At the October "Open House" the parents were told of the school's Basic Skills Program and of what areas in reading and math that would be emphasized. Those areas were correlated to the district report card, so that parents could easily see the progress of the program as the year ensued. The theme of the open House was "Homework" and the parents were shown a slide show that demonstrated ways to help their children with 
homework. The slide show was developed by the Vice Principal and Learning Specialist of Clackamas Elementary. The purpose of the slide show was to help establish teachers and parents as partners in the attempt to bring up skills. Underlying the basic philosophy of developing a homework policy is the effective school variable that indicated that more time spent on a subject will produce greater mastery of the skill. Grade level meetings were also used to develop another effective school variable--that of an effective staff training program. As a part of the meetings, the basal reading materials were analyzed and consultants were brought in to better explain the materials. The areas that were emphasized in the Basic Skills Program were found in the basal reading program and marked in the teacher's manual so that when the teacher came to that page in the manual, he/she would be reminded to emphasize that concept. The staff also worked together during the grade level meetings and staff meetings to develop the homework policy.

The effective school variable of control and disicpline had been improved the year before at Clackamas Elementary with the development of a Discipline Policy that can be found in Appendix $F$. The policy stated that a student would be suspended if any one of the following three rules were violated: (1) assault of another student 
or any school employee, (2) willful disobedience of a staff member, (3) use of profane or obscene language or gestures. A time-out procedure was also established (described in Appendix G), where a student could spend as much as a half-hour in another room because of disruptive behavior, to finish work, or for health reasons. After five timeouts, the parents would be notified and after ten time outs the parents, teacher and principal would have a conference for the purpose of designing a plan to deal with future problems.

A proactive plan to develop a positive school climate was developed during the treatment year. A Citizen of the Month assembly was held regularly where a student from each class was recognized by the student body and parents. Their names were published in the school paper and their pictures hung in the hall for a month. A student of the Week was announced over the intercom each Friday in recognition of accomplishments in academic work and for good behavior. A student council was established. The council raised money for the school and organized activities for the student body, such as "Balloon Day" and "Dress Up Like Your Favorite Book Character Day."

\section{Sampling Procedures and Considerations}

The students in grades four, five and six at Clackamas Elementary School were compared to the control 
group (which was the class of each grade level of the previous year). The groups in the study were intact groups and totalled 120 students. The control group was selected because it dealt with the same type of population. If another school had been used as a control group, internal validity would have been jeopardized. The pretest NCE means of both the control and treatment groups were analyzed to determine if the groups were comparable.

\section{Design of the Investigation}

The design of the study was a pretest-treatmentposttest model. This quasi-experimental design, repeated by grade level across time, compared the California Achievement Test results of the Spring of 1983 with the results of spring of 1982. Only the areas emphasized by the Basic Skills Program were analyzed for change. The weak areas in reading comprehension were recall of facts, identifying fact and opinion, identifying main idea, and characteristic analysis. The low areas in math were addition, subtraction, multiplication, and story problems.

\section{Statistical Treatment of Data}

The effect of the program to improve test scores of low areas as determined by results of the California Achievement Test was evaluated by comparing pretreatment 
and posttreatment scores on the California Achievement Test using a multivariate analysis of variance of pre-post NCE change scores for the three subscales (dependent variables). The three subscales were reading comprehension, math comprehension, and math concepts. A univariant analysis of variance was then applied to each subscale separately. A $t$ test for dependent samples was then used to compare pretest to posttest NCE change score means within each of the control and treatment groups for each subscale separately. Alpha level was set at the .05 for each of the above tests.

To establish the comparability of the treatment and control groups three methods were used. A chi square test of independence was performed using free, reduced, and regular lunch as one variable and treatment and control groups as the other variable. The drop-out percentages were used as the second test of group comparability. A chi square test for the independent percents was applied to the drop out percents. Finally, as a test on group comparability a test between treatment and control grade level groups was used to determine pretest differences. After one year of the Basic Skills program, (Spring, 1983), teachers completed a questionnaire. The survey was used to measure teacher attitudes about their expectations for student achievement, their attitudes 
about the effect of the Basic Skills Program, the instructional leadership of the principal, and how much time was spent teaching basic skills. The survey also gave the teachers an opportunity to make suggestions for next year's program. Analyzing the results of the survey helped determine if, in fact, many of the effective school variables that the administration felt had been implemented on the surface had indeed been accepted and internalized by each teacher. The survey appears in Appendix $\mathrm{H}$. 
CHAPTER IV

\section{RESULTS AND ANALYSIS}

The research hypothesis for the study stated: The Basic Skills Program at Clackamas Elementary School will result in a significant change in students' relative position compared with the norming sample as measured on the California Achievement Test from one Spring to the next spring. The design was test-treatment-test. The California Achievement Test results were analyzed (Spring 1982, ) and four low areas were identified in reading and math. The Basic Skills Program was then developed that would allow for staff to concentrate on teaching to those low areas that were identified during the next year. In the Spring of 1983 the California Achievement Test was given again and the areas that were emphasized in the Basic Skills Program were analyzed to see if the program significantly affected the scores in a positive direction.

\section{Demographic Description of Treatment and Control Groups}

The treatment group in this study consisted of fourth, fifth, and sixth grade students at Clackamas Elementary School, North Clackamas School District \#12. 
The California Achievement Test was used for both pretesting and posttesting to determine achievement levels. The pretest was given to this group in the spring, of 1982 and the posttest was given in the Spring, 1983. All students were required to participate. A total of 29 fourth graders, 37 fifth graders, and 30 sixth graders completed both the pretest and postest.

The control group in this study were also fourth, fifth and sixth grade students at Clackamas Elementary School, North Clackamas School District \#12. The control group took the California Achievement Test one year before the treatment group; during the spring of 1981 the pretest was administered and in the spring of 1982 , the posttest was given. This group was chosen for the control group because it represented the same population as the treatment group. In fact, 75 of the students who were in the treatment group were also in the control group, but at a different grade level. As with the treatment group, only the students who completed the pretest and posttest were included in the control group analysis. Table I compares the demographic characteristics of the treatment and control groups.

Socio-Economic Status of the Population

Information regarding school lunch was used to indicate the socio-economic status of the control and 
TABLE I

COMPARISON OF DEMOGRAPHIC CHARACTERISTICS OF THE TREATMENT AND CONTROL GROUPS

\begin{tabular}{|c|c|c|}
\hline Group & Treatment & Control \\
\hline & Sex & \\
\hline Male & 48 & 57 \\
\hline \multirow[t]{2}{*}{ Female } & 48 & 54 \\
\hline & Grade Level & \\
\hline Fourth & 29 & 35 \\
\hline Fifth & 37 & 39 \\
\hline \multirow[t]{2}{*}{ Sixth } & 30 & 37 \\
\hline & Lunch Information & \\
\hline \multicolumn{3}{|l|}{ Fourth } \\
\hline $\begin{array}{l}\text { Free } \\
\text { Reduced }\end{array}$ & $\begin{array}{r}4 \\
3 \\
? ?\end{array}$ & $\begin{array}{r}5 \\
3 \\
2 ?\end{array}$ \\
\hline \multicolumn{3}{|l|}{ Fifth } \\
\hline $\begin{array}{l}\text { Free } \\
\text { Reduced }\end{array}$ & $\begin{array}{l}8 \\
4\end{array}$ & $\begin{array}{l}8 \\
4\end{array}$ \\
\hline Regular & 25 & 25 \\
\hline \multicolumn{3}{|l|}{ Sixth } \\
\hline Free & 2 & 2 \\
\hline Reduced & 0 & 2 \\
\hline Regular & 22 & 28 \\
\hline \multicolumn{3}{|l|}{ Total } \\
\hline Free & 14 & 15 \\
\hline Reduced & 13 & 9 \\
\hline Regular & 69 & 75 \\
\hline
\end{tabular}


treatment groups. A high rate of free and reduced student lunches indicates that this study was done in a low socio-economic area. The treatment group had 14 free lunches, 7 reduced lunches and 69 regular lunches. The control group had 15 free lunches, 9 reduced lunches and 75 regular lunches.

Another indicator of a low socio-economic status of the groups was the high rate of mobility which was represented by the percentage of students who were not included in the study because they lacked the pretest and the posttest scores. A total of 158 students out of a possible 365 were not included in the treatment or control groups because they did not attend school long enough to complete the pretest and posttest. This mobility rate indicates an unstable population. Table II compares the percentage of students who dropped out at each grade level for the control and treatment groups.

\section{Comparability of Treatment and Control Groups}

One method used to establish the comparability of the treatment and control groups was to compare the use of free and reduced lunch by these groups (see Table III). A chi square test of independence was performed, using free, reduced and regular lunch as one variable and treatment and control group as the other variable. The calculated chi square value was .1061. With $2 \mathrm{df}$, the table value of 
TABLE II

DROPOUTS FROM THE CONTROL AND TREATMENT GROUPS

\begin{tabular}{|c|c|c|c|}
\hline \multirow[b]{2}{*}{ Group } & \multicolumn{3}{|c|}{ Status in Program } \\
\hline & $\overline{\text { Began }}$ & Finished & Dropout $\%$ \\
\hline \multicolumn{4}{|c|}{ Control Group } \\
\hline Fourth & 59 & 35 & 41 \\
\hline Fifth & 58 & 40 & 32 \\
\hline Sixth & 52 & 38 & 27 \\
\hline Total & 169 & 113 & 33 \\
\hline \multicolumn{4}{|c|}{ Treatment Group } \\
\hline Fourtin & 39 & 30 & 24 \\
\hline Fifth & 47 & 37 & 22 \\
\hline Sixth & 52 & 31 & 41 \\
\hline Total & 138 & 98 & 28 \\
\hline \multicolumn{4}{|c|}{ Combined Years } \\
\hline Fourth & 98 & 60 & 38 \\
\hline Fifth & 105 & 77 & 27 \\
\hline Sixth & 104 & 69 & 34 \\
\hline Total & 307 & 211 & 28 \\
\hline
\end{tabular}


TABLE III

LUNCH POOLED GRADE COMPARISONS

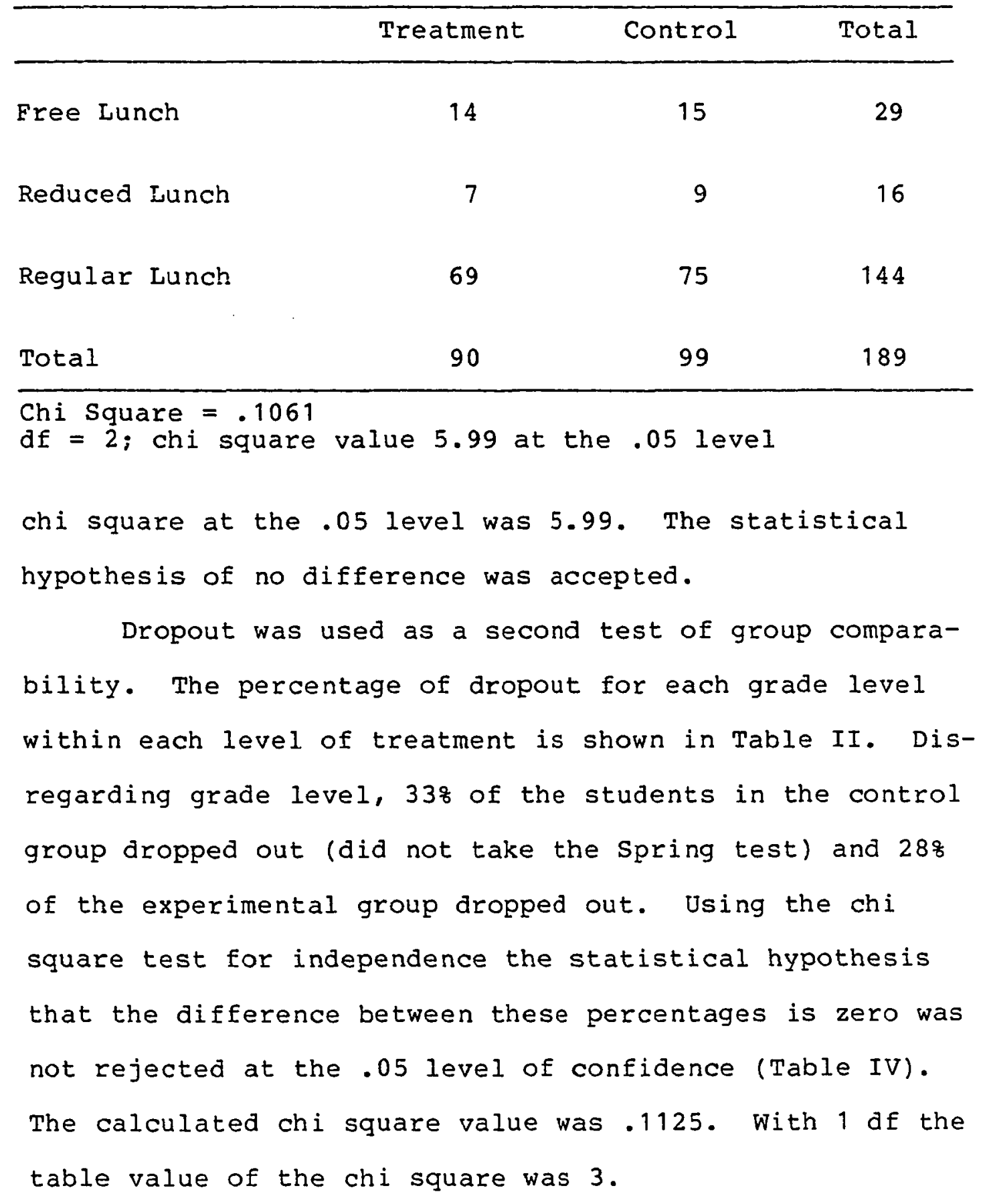


TABLE IV

DROPOUT RATE COMPARISONS

\begin{tabular}{lccc}
\hline & Treatment & Control & Total \\
\hline Remaining & 138 & 169 & 307 \\
Dropped out & 98 & 113 & 211 \\
Total & 236 & 282 & 518 \\
\hline
\end{tabular}

Chi Square $=.1125$

$\mathrm{df}=1$ and level of .05, chi square value 3

Finally, as a test on group comparability, a $t$ test between groups was used to determine pretest differences. Table $V$ shows the results of the test. The $t$ test results on the pretest NCE scores indicate that there was no significant difference in the treatment and control group means for reading comprehension, math comprehension and math concepts for the fourth grade $(p<.05)$. The fifth grade results indicate that the treatment and control groups were significantly different in pretest NCE scores in the areas of reading comprehension $(p=.02)$ and math comprehension $(p<.05)$. In both sub-scale tests, of the control group, the NCE mean was lower than the treatment group NCE mean. There was no significant difference between the control and treatment groups in the fifth grade for math. There was no significant difference 
TABLE V

$t$ TEST BETWEEN GROUPS ON PRETEST TO PRETEST DIFFERENCES FOR CONTROL AND TREATMENT GROUPS

\begin{tabular}{|c|c|c|c|c|c|c|}
\hline Variable & Cases & Mean & $\begin{array}{l}\text { Stand. } \\
\text { Dev. }\end{array}$ & $\begin{array}{c}t^{t} \\
\text { value }\end{array}$ & $d f$ & $\begin{array}{l}\text { Sig. } \\
\text { Level }\end{array}$ \\
\hline \multicolumn{7}{|c|}{ Grade 4} \\
\hline \multicolumn{7}{|c|}{$\begin{array}{l}\text { Reading } \\
\text { Comprehension }\end{array}$} \\
\hline Control & 35 & 53.8 & 19.3 & \multirow[b]{2}{*}{1.33} & \multirow[b]{2}{*}{53.3} & \multirow[b]{2}{*}{.18} \\
\hline Treatment & 29 & 46.4 & 24.0 & & & \\
\hline \multicolumn{7}{|c|}{ Math } \\
\hline Comprehens i & & & & \multirow{3}{*}{-1.93} & & \\
\hline Control & 35 & 38.7 & 20.6 & & \multirow{2}{*}{55.4} & \multirow{2}{*}{.30} \\
\hline Treatment & 39 & 44.6 & 24.1 & & & \\
\hline \multirow{2}{*}{\multicolumn{7}{|c|}{$\begin{array}{l}\text { Math } \\
\text { Concepts }\end{array}$}} \\
\hline & & & & \multirow{3}{*}{.93} & \multirow{3}{*}{61.6} & \multirow{3}{*}{.35} \\
\hline Control & 35 & & 19.7 & & & \\
\hline Treatment & 29 & 46.1 & 17.5 & & & \\
\hline \multicolumn{7}{|c|}{ Grade 5} \\
\hline \multicolumn{7}{|c|}{$\begin{array}{l}\text { Reading } \\
\text { Comprehension }\end{array}$} \\
\hline Control & 39 & 48.3 & 16.8 & \multirow{2}{*}{-2.38} & \multirow{2}{*}{73.6} & \multirow{2}{*}{$.02 *$} \\
\hline Treatment & 37 & 57.6 & 17.1 & & & \\
\hline \multicolumn{7}{|c|}{ Math Comprehension } \\
\hline Control & 39 & 39.3 & 18.4 & \multirow{2}{*}{$-1,99$} & \multirow{2}{*}{73.4} & \multirow{2}{*}{$.05 *$} \\
\hline Treatment & 37 & 47.2 & 16.0 & & & \\
\hline \multicolumn{7}{|l|}{$\begin{array}{l}\text { Math } \\
\text { Concepts }\end{array}$} \\
\hline Control & 39 & 43.1 & 19.0 & \multirow{2}{*}{-1.45} & \multirow{2}{*}{71.4} & \multirow{2}{*}{.15} \\
\hline Treatment & 37 & 48.8 & 14.9 & & & \\
\hline
\end{tabular}


TABLE V (continued)

\begin{tabular}{|c|c|c|c|c|c|c|}
\hline Variable & Cases & Mean & $\begin{array}{l}\text { Stand. } \\
\text { Dev. }\end{array}$ & $\begin{array}{c}t \\
\text { value }\end{array}$ & $d f$ & $\begin{array}{l}\text { Sig. } \\
\text { Level }\end{array}$ \\
\hline \multicolumn{7}{|c|}{ Grade 6} \\
\hline \multicolumn{7}{|c|}{$\begin{array}{l}\text { Reading } \\
\text { Comprehension }\end{array}$} \\
\hline Control & 37 & 50.2 & 16.4 & \multirow{2}{*}{-0.78} & \multirow{2}{*}{58.0} & \multirow{2}{*}{.43} \\
\hline Treatment & 30 & 53.6 & 18.8 & & & \\
\hline \multicolumn{7}{|c|}{ Math } \\
\hline Control & 37 & 44.00 & 19.4 & \multirow[b]{2}{*}{-1.79} & \multirow[b]{2}{*}{63.5} & \multirow[b]{2}{*}{.07} \\
\hline Treatment & 30 & 52.2 & 18.2 & & & \\
\hline \multicolumn{7}{|l|}{$\begin{array}{l}\text { Math } \\
\text { Concepts }\end{array}$} \\
\hline Treatment & 37 & 50.1 & $\begin{array}{l}14.8 \\
15.4\end{array}$ & -1.18 & 61.0 & .24 \\
\hline
\end{tabular}

between the control and treatment groups in reading comprehension, math comprehension and math concepts $(p<.05)$ for the sixth grade.

\section{Procedures Used In Statistical Analysis}

Two different statistical approaches were used to analyze the data from the study. Normal Curve Equivalents (NCE scores) were used for the statistical analysis. NCE scores are explained further in Appendix A. First, the three sub-scales (Reading Comprehension, Math 
Comprehension and Math Concepts) from the California Achievement Test were analyzed by using a multivariant analysis of variance on the NCE change scores for the control and treatment groups. Following the rejection of the statistical hypothesis for the main effect for treatment in the multivariant analysis of variance, a univariant analysis was applied to each dependent variable separately.

The second approach was a $t$ test for dependent groups to check on the effectiveness of each grade level on the achievement of the students between pretesting and posttesting. A negative change in NCE scores would indicate a loss of selective position of students in the norming sample, a zero indicates maintenance of the same relative position and a plus gain indicates an improvement of position. Confidence Intervals (.95) were also used to determine the effectiveness of the treatment on the three sub-scales.

\section{Analysis of Difference in NCE Gain Scores Between} Control and Treatment Groups

Analysis of Variance, Multivariate Pre-Post Gain Scores

A multivariate analysis of variance followed by univariate analysis, were performed on the change scores for the dependent variable. In the multivariant analysis of 
variance, the statistical hypothesis for the interaction was not rejected, $(p=.697)$, therefore, the main effects were examined. The results of the multivariant analysis of variance are presented in Table VI.

TABLE VI

MANOVA ON GAIN SCORES BETWEEN CONTROL

AND TREATMENT GROUPS

\begin{tabular}{|c|c|c|c|c|c|}
\hline \multicolumn{6}{|c|}{ Treatment by Grade } \\
\hline Test Name & Value & Approx. F & Hyp. df & Error df & $\begin{array}{l}\text { Sig. } \\
\text { of } F\end{array}$ \\
\hline Pillais & .01908 & .6421 & 6.00 & 400.00 & .697 \\
\hline \multicolumn{6}{|c|}{ Grade Effect } \\
\hline Pillais & .0555 & 1.904 & 6.00 & 400.00 & .079 \\
\hline \multicolumn{6}{|c|}{ Treatment Effect } \\
\hline Pillais & .0804 & 5.799 & 3.00 & 199.00 & .001 \\
\hline
\end{tabular}

As shown in Table VI, the calculated Pillais $F$ for grade level interaction was 1.904; with 6 and 400 degrees of freedom, the statistical hypothesis was not rejected at the .05 level of confidence $(p=.079)$. For the treatment effect, the calculated Pillais $F$ was 5.799 . The statistical hypothesis that the two populations as represented by the treatment and control groups do not differ in NCE 
change score means in reading comprehension, math comprehension, and math concepts was rejected at the .05 level of confidence $(p=.001)$. Therefore, the arrays of means for the two populations are not equal.

\section{Analysis of Variance, Univariant Test of Means}

Following the rejection of the multivariate statistical hypothesis concerning treatment, a factorial analysis of variance was performed on each dependent variable. Since the statistical hypothesis concerning interaction was not rejected in the multivariate case, univariate interactions were not examined. And, since the statistical hypothesis concerning grade level main effects was not rejected in the multivariate case, grade level differences were not examined in the univariate analysis. Therefore, only the treatment main effects were examined. The statistical hypotheses that the NCE change score means of the two populations are equal was not rejected for reading comprehension $(p=.72)$; it also was not rejected for math concepts $(p=.10)$. The statistical hypothesis that the NCE change score mean of the two populations are equal was rejected for math comprehension $(p=.001)$. The research hypothesis that the population which did not receive treatment would have a greater positive NCE mean change score than would the population which received the treatment was accepted. The results of the analysis of variance on mean gain score is shown in Table VII. 
TABLE VII

ANALYSIS OF VARIANCE ON MEAN GAIN SCORES TEST OF SIGNIFICANCE FOR SUB SCALES OF THE TREATMENT AND CONTROL GROUPS

\begin{tabular}{|c|c|c|c|c|c|}
\hline \multicolumn{6}{|c|}{ Reading Competencies } \\
\hline Source & $\begin{array}{l}\text { Sum of } \\
\text { Squares }\end{array}$ & $d f$ & Mean Square & $\mathbf{E}$ & $\underset{F}{\operatorname{Sig}}$ of \\
\hline Treatment & 19.9 & 1 & 19.9 & .122 & .72 \\
\hline Grade & 13.4 & 2 & 6.70 & .041 & .96 \\
\hline $\begin{array}{l}\text { Teatment } \\
\text { by Grade }\end{array}$ & 287 & 2 & 143.84 & .885 & .41 \\
\hline $\begin{array}{c}\text { Within } \\
\text { Cells }\end{array}$ & 33138.96 & 204 & 162.44 & & \\
\hline \multicolumn{6}{|c|}{ Math Competencies } \\
\hline Treatment & 3240.67 & 1 & 3240.67 & 15.5 & $.00 *$ \\
\hline Grade & 814.77 & 2 & 407.38 & 1.95 & .14 \\
\hline $\begin{array}{l}\text { Treatment } \\
\text { by Grade }\end{array}$ & 371.49 & 2 & 185.74 & .89 & .41 \\
\hline $\begin{array}{c}\text { Within } \\
\text { Celis }\end{array}$ & 42238.36 & 203 & 208.07 & & \\
\hline \multicolumn{6}{|c|}{ Math Concepts } \\
\hline Treatment & 385.32 & 1 & 385.32 & 2.67 & .10 \\
\hline Grade & 1291.75 & 2 & 645.87 & 4.47 & $.01 *$ \\
\hline $\begin{array}{r}\text { Within } \\
\text { Cells }\end{array}$ & 28995.28 & 201 & 144.25 & & \\
\hline
\end{tabular}

$\star p<.01$ 
Pre-To-Post $t$ On NCE Scores within Groups

As can be seen in Tables VIII, IX, and $\mathrm{X}$, there was a significant gain in NCE change score mean for the control group from pretest to postest on math comprehension at all grade levels $(\mathrm{p}=.01$ in all cases). For the treatment group, a significant gain in NCE scores pretest to posttest on math comprehension was detected only at the sixth-grade level $(p=.01)$; the differences were not significant at the other grade levels.

By examining Tables VIII, IX, and $X$, it can be seen that there was no-significant gain in $\mathrm{NCE}$ scores at any grade level between pretest and posttest on reading comprehension for the control group. However, for the fifth-grade treatment group there was a significant gain between pretest and posttest NCE scores for reading comprehension $(p=.05)$; the differences were not significant for other grade levels.

As indicated in Tables VII, IX, and $X$, only one significant difference was detected between pretest and posttest math concepts NCE scores; the sixth grade control groups demonstrated a statistically significant gain $(p=.02)$.

Thus, out of the eighteen $t$ tests performed, six were significant--four for the control groups and two for the treatment groups. Figure 1 displays the $t$ test means on gain scores for the treatment and control groups. 
TABLE VIII

STUDENT $t$ TEST PRE-POST GROWTH WITHIN GROUPS ON NCE SCORES

\begin{tabular}{|c|c|c|c|c|c|c|c|}
\hline & & Grade 4 & - Control & Group & & & \\
\hline Variable & Case & Mean & $\begin{array}{l}\text { Stand. } \\
\text { Dev. }\end{array}$ & $\begin{array}{l}\text { Diff. } \\
\text { Mean }\end{array}$ & $\begin{array}{l}t \text { val } \\
\text { sig. }\end{array}$ & $\begin{array}{l}\text { lue } c \\
\text { leve }\end{array}$ & $\begin{array}{l}\partial f \\
e l\end{array}$ \\
\hline $\begin{array}{l}\text { Reading Comp } \\
\text { post test }\end{array}$ & 35 & 57.5 & 17.2 & 3.68 & 1.70 & 34 & .09 \\
\hline $\begin{array}{l}\text { Reading Comp. } \\
\text { pretest }\end{array}$ & & 53.8 & 19.3 & & & & \\
\hline $\begin{array}{l}\text { Math Comp } \\
\text { posttest }\end{array}$ & 35 & 48.5 & 15.7 & 9.77 & 4.26 & 34 & $.00 *$ \\
\hline $\begin{array}{l}\text { Math Comp. } \\
\text { pretest }\end{array}$ & & 38.7 & 20.6 & & & $\cdot$ & \\
\hline $\begin{array}{l}\text { Math Concepts } \\
\text { posttest }\end{array}$ & 35 & 50.0 & 14.8 & -.48 & -0.29 & 34 & .77 \\
\hline \multirow[t]{2}{*}{$\begin{array}{l}\text { Math Concepts } \\
\text { pretest }\end{array}$} & & 50.5 & 19.7 & & & & \\
\hline & & Grade 4 & Treatment & Group & & & \\
\hline $\begin{array}{l}\text { Reading Comp. } \\
\text { posttest }\end{array}$ & 30 & 48.0 & 19.8 & 1.06 & .37 & 29 & .71 \\
\hline $\begin{array}{l}\text { Reading Comp } \\
\text { pretest }\end{array}$ & & 46.9 & 23.7 & & & & \\
\hline $\begin{array}{l}\text { Math Comp. } \\
\text { posttest }\end{array}$ & 29 & 43.1 & 19.0 & -1.51 & -0.52 & 28 & .60 \\
\hline $\begin{array}{l}\text { Math Comp } \\
\text { pretest }\end{array}$ & & 44.6 & 24.1 & & & & \\
\hline $\begin{array}{l}\text { Math Concepts } \\
\text { posttest }\end{array}$ & 29 & 41.6 & 16.3 & -503 & -1.88 & 28 & .07 \\
\hline $\begin{array}{l}\text { Math Concepts } \\
\text { pretest }\end{array}$ & & 46.1 & 17.5 & & & & \\
\hline
\end{tabular}


TABLE IX

STUDENT $t$ TEST PRE-POST GROWTH WITHIN

GROUPS ON NCE SCORES

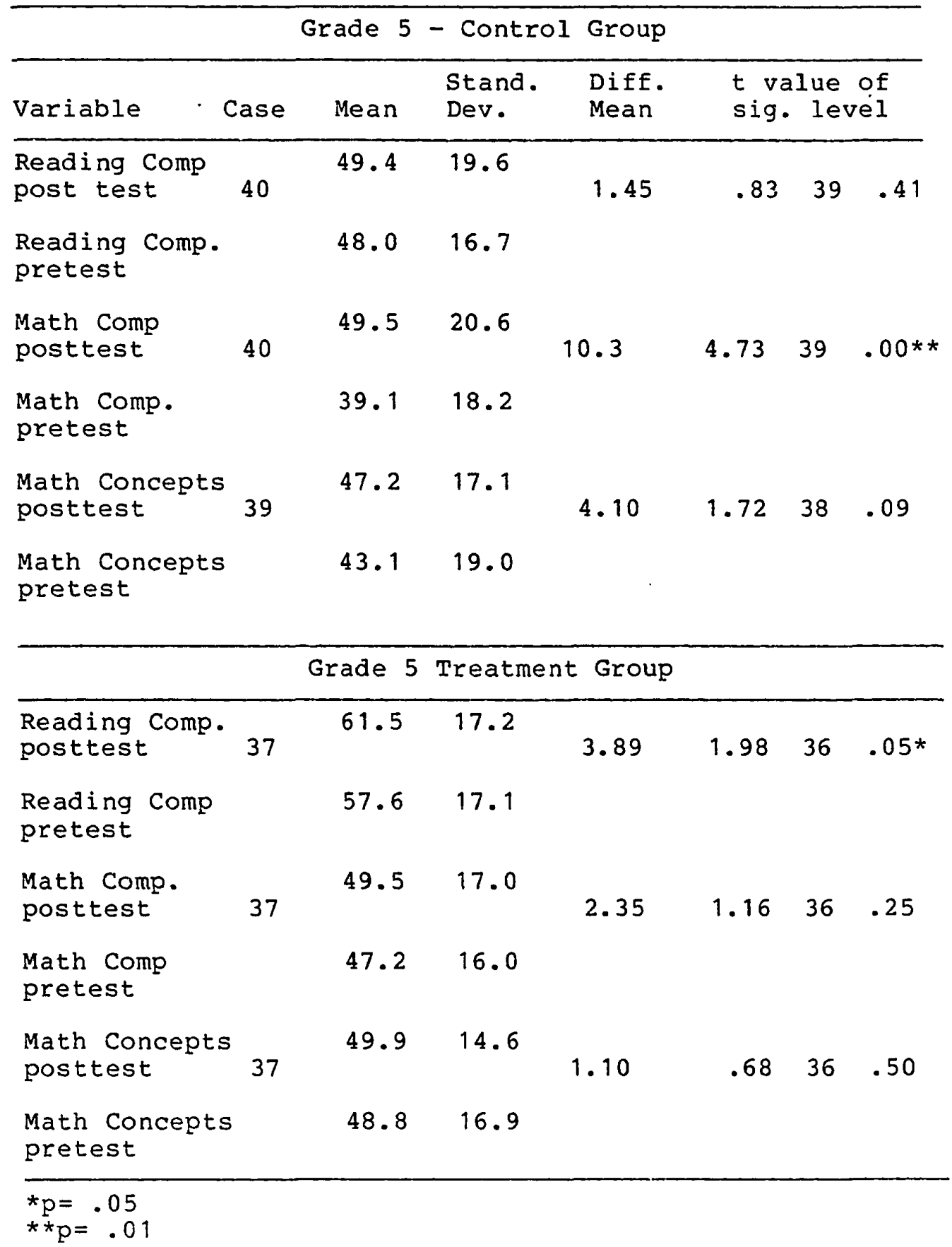


TABLE $X$

STUDENT $t$ TEST PRE-POST GROWTH WITHIN

GROUPS ON NCE SCORES

\begin{tabular}{|c|c|c|c|c|c|c|c|}
\hline & & Grade 6 & - Contro & I Group & & & \\
\hline Variable & Case & Mean & $\begin{array}{l}\text { Stand. } \\
\text { Dev. }\end{array}$ & $\begin{array}{l}\text { Diff. } \\
\text { Mean }\end{array}$ & $\begin{array}{l}t \text { va } \\
\text { sig. }\end{array}$ & $\begin{array}{l}\text { lue } \\
\text { lev }\end{array}$ & $\begin{array}{l}\text { of } \\
\text { rel }\end{array}$ \\
\hline $\begin{array}{l}\text { Reading Comp } \\
\text { posttest }\end{array}$ & 37 & 53.2 & 17.8 & 3.05 & 1.55 & 36 & .13 \\
\hline $\begin{array}{l}\text { Reading Comp. } \\
\text { pretest }\end{array}$ & & 50.2 & 16.4 & & & & \\
\hline $\begin{array}{l}\text { Math Comp } \\
\text { posttest }\end{array}$ & 37 & 55.6 & 15.3 & 11.64 & 4.41 & 36 & $.00 * *$ \\
\hline $\begin{array}{l}\text { Math Comp. } \\
\text { pretest }\end{array}$ & & 44.0 & 19.4 & & & & \\
\hline $\begin{array}{l}\text { Math Concepts } \\
\text { post test }\end{array}$ & 37 & 49.1 & 17.5 & 3.40 & 2.28 & 36 & $.02 * \star$ \\
\hline \multirow[t]{2}{*}{$\begin{array}{l}\text { Math Concepts } \\
\text { pretest }\end{array}$} & & 45.7 & 14.8 & & & & \\
\hline & & Grade 6 & Treatmer & nt Group & & & \\
\hline $\begin{array}{l}\text { Reading Comp. } \\
\text { posttest }\end{array}$ & 31 & 54.0 & 16.2 & .83 & .35 & 30 & .73 \\
\hline $\begin{array}{l}\text { Reading Comp } \\
\text { pretest }\end{array}$ & & 53.2 & 18.6 & & & & \\
\hline $\begin{array}{l}\text { Math Comp. } \\
\text { posttest }\end{array}$ & 31 & 58.1 & 13.9 & 7.09 & 2.60 & 30 & $.01 *$ \\
\hline $\begin{array}{l}\text { Math Comp } \\
\text { pretest }\end{array}$ & & 51.0 & 19.1 & & & & \\
\hline $\begin{array}{l}\text { Math Concepts } \\
\text { posttest }\end{array}$ & 30 & 52.6 & 15.1 & 5.50 & 1.04 & 29 & .30 \\
\hline $\begin{array}{l}\text { Math Concepts } \\
\text { pretest }\end{array}$ & & 50.1 & 15.4 & & & & \\
\hline
\end{tabular}




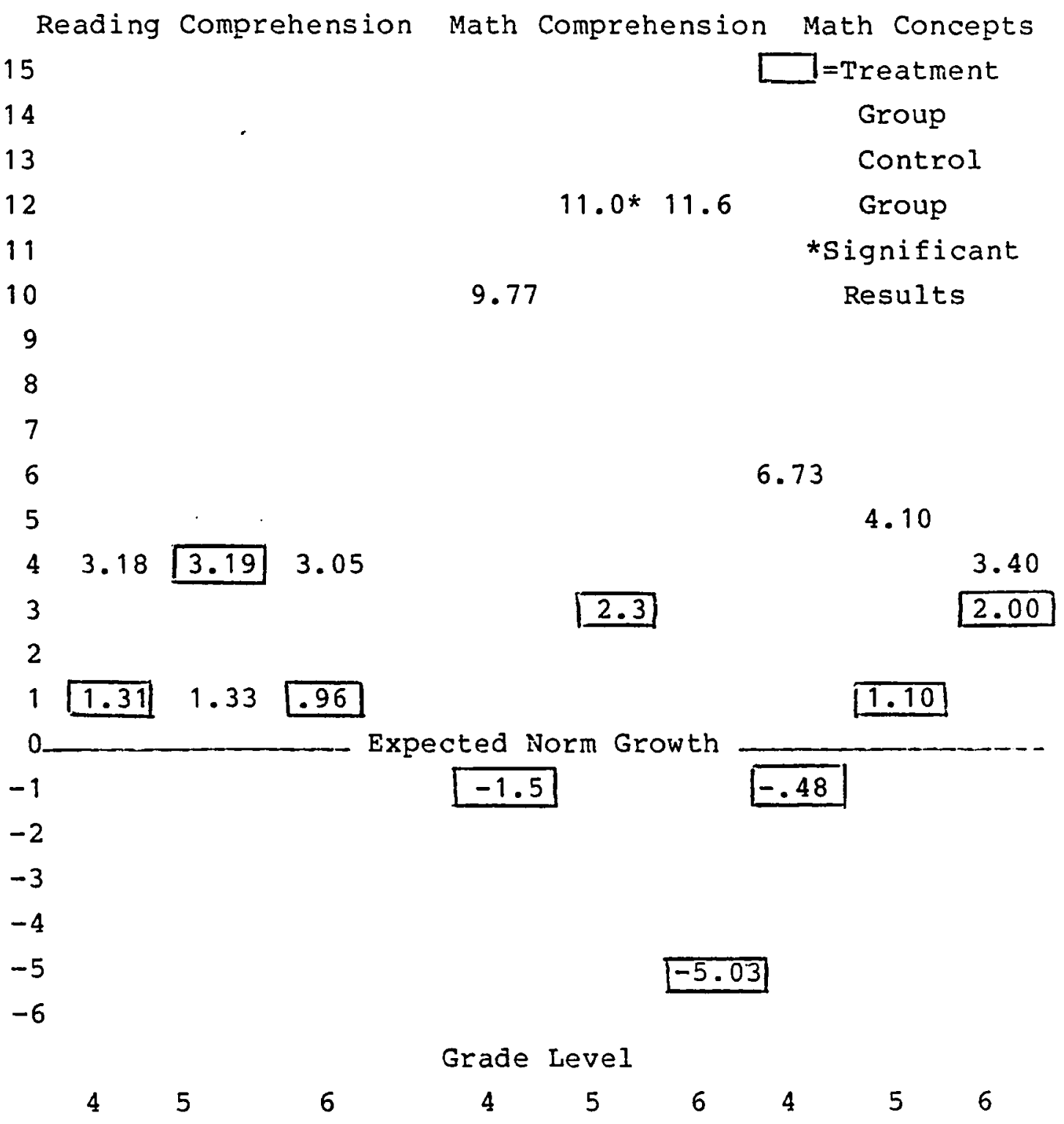

Figure 1. Means on Gain Scores for Treatment and Control Groups. 


\section{Confidence Intervals on Mean Scores}

Since NCE scores are anchored to norming sample performance, a change score mean of zero indicates that the group maintained its same relative position within the norming population from the pretest to posttest. When a confidence interval around a group's NCE change score mean includes zero, it is reasonable to consider the group's performance to be fairly consistent in comparison to the norming sample performance. As can be seen in Table XI, the .95 confidence interval around the group mean includes zero for each grade level within each treatment group for reading comprehension. For math comprehension, the confidence intervals around the grade-level control group means did not trap zero--lower limits of all intervals were above this value. For the treatment groups on math comprehension only the confidence interval for the sixth grade did not include zero; its lower limit was above zero. With the exception of the sixth grade control group all of the confidence intervals around group means for math concepts included zero; for this group the lower limits of the confidence interval was above zero.

\section{Teacher Involvement and Attitudes}

The teachers who were involved in the treatment program were given a survey in the spring of 1983, after the 
TABLE XI

TABLE OF MEANS, STANDARD DEVIATIONS AND CONEIDENCE INTRVALS, ON GAIN SCORES FOR THE TREATMENT AND CONTROL GROUPS

\begin{tabular}{|c|c|c|c|c|c|}
\hline \multicolumn{6}{|c|}{ Reading Competencies } \\
\hline Factor & Grade & Mean & std. Dev. & $\mathbf{N}$ & .95 Conf. Interval \\
\hline Control & $\begin{array}{l}4 \\
5 \\
6\end{array}$ & $\begin{array}{l}3.68 \\
1.33 \\
3.05\end{array}$ & $\begin{array}{l}12.79 \\
11.12 \\
12.00\end{array}$ & $\begin{array}{l}35 \\
39 \\
37\end{array}$ & $\begin{array}{l}-0.708<->8.07 \\
-2.27 \longleftrightarrow->4.93 \\
-0.94 \longleftrightarrow->7.05\end{array}$ \\
\hline Treatment & $\begin{array}{l}4 \\
5 \\
6\end{array}$ & $\begin{array}{l}1.31 \\
3.89 \\
0.96\end{array}$ & $\begin{array}{l}15.81 \\
11.95 \\
13.71\end{array}$ & $\begin{array}{l}29 \\
37 \\
30\end{array}$ & $\begin{array}{l}-4.70<ـ>7.32 \\
-0.29<->7.87 \\
-4.15<ـ>6.08\end{array}$ \\
\hline \multicolumn{6}{|c|}{ Math Competencies } \\
\hline Control & $\begin{array}{l}4 \\
5 \\
6\end{array}$ & $\begin{array}{r}9.77 \\
11.05 \\
11.64\end{array}$ & $\begin{array}{l}13.57 \\
13.38 \\
16.05\end{array}$ & $\begin{array}{l}35 \\
39 \\
37\end{array}$ & $\begin{array}{l}5.10<->4.43 \\
6.71 \longleftrightarrow->5.38 \\
6.29 \longleftrightarrow->7.00\end{array}$ \\
\hline Treatment & $\begin{array}{l}4 \\
5 \\
6\end{array}$ & $\begin{array}{r}-1.51 \\
2.35 \\
6.73\end{array}$ & $\begin{array}{l}15 \cdot 56 \\
12 \cdot 32 \\
15 \cdot 30\end{array}$ & $\begin{array}{l}29 \\
37 \\
30\end{array}$ & $\begin{array}{r}-7.43 \longleftrightarrow \longrightarrow>4.40 \\
-1.75 \longleftrightarrow->6.46 \\
1.01 \longleftrightarrow->2.44\end{array}$ \\
\hline \multicolumn{6}{|c|}{ Math Concepts } \\
\hline Control & $\begin{array}{l}4 \\
5 \\
6\end{array}$ & $\begin{array}{r}-0.48 \\
4.10 \\
3.40\end{array}$ & $\begin{array}{r}9.76 \\
14.85 \\
9.08\end{array}$ & $\begin{array}{l}35 \\
39 \\
37\end{array}$ & $\begin{array}{r}-3.83<->2.87 \\
-.071<->8.91 \\
0.37<->6.43\end{array}$ \\
\hline Treatment & $\begin{array}{l}4 \\
5 \\
6\end{array}$ & $\begin{array}{r}-5.03 \\
1.10 \\
2.50\end{array}$ & $\begin{array}{r}14.40 \\
9.93 \\
13.16\end{array}$ & $\begin{array}{l}29 \\
37 \\
30\end{array}$ & $\begin{array}{r}-10.51 \longleftrightarrow \longrightarrow .44 \\
-2.20 \longleftrightarrow->4.42 \\
-2.41 \longleftrightarrow->7.41\end{array}$ \\
\hline
\end{tabular}


treatment was completed. The purpose of the survey was to assess the teacher attitudes and involvement in the treatment program. The survey was also designed so that other characteristics could be analyzed: (1) if the attitudes of the teachers involved in the program coincide with known attitudes of teachers in effective schools; (2) if the attitudes of teachers in the program vary across grade level; (3) if teachers believed the program was effective; (4) how much time was spent on the program in the classroom; (5) and what changes teachers would make in the program for the following year. Appendix B displays the teacher survey.

Results of the Survey

The survey of teachers at the end of the treatment was designed with four to five questions under each subscale. As Table XII indicates the teachers generally felt that the test scores should be analyzed and programs developed to improve weak areas. However, they were uncertain that the California Achievement Test measured skills children need to develop and were uncertain that the test measured grade level expectations that they had for their grade level.

As can be seen in Table XIII, teachers generaliy felt that students from low socio-economic backgrounds could be expected to perform at a low academic level and 
TABLE XII

TEACHER ATTITUDES ON MEASURING EFFECTIVENESS THROUGH EVALUATION OF TEST RESULTS

\begin{tabular}{lll}
\hline Statement & $\begin{array}{l}\text { Strongly } \\
\text { Agree }\end{array} \quad$ Agree Uncertain Disagree Disagree \\
\hline
\end{tabular}

1. Low scores on the California Achievement Test should be Analyzed so that weak

Academic areas can be identified

2

4

6. Programs should be developed that would improve the weak California Achlevement Test Scores

1

2

1

1

11. Bringing up California Achievement Test scores would improve skills children need to improve

1

3

1

1

16. California Achlevement Test is an achlevement test that tests grade level expectations for my grade level 
TABLE XIII

TEACHER ATTITUDES AND EXPECTATIONS

FOR STUDENT ACHIEVEMENT

\begin{tabular}{llll}
\hline Statement & $\begin{array}{l}\text { Strongly } \\
\text { Agree }\end{array}$ & Agree Uncertain Disagree Disagree \\
\hline
\end{tabular}

2. Students of low socio/economic backgrounds can be expected to perform at a low academic level

1

1

3

1

17. Measured progress of a student

from a low socio/economic

background can be expected to

be slow

2

3

1

12. Teachers should reduce some prlority goals for certain low performing students

5

1

21. Teachers can teach all students all students can master priority objectives

2

2

2 
that measured progress for these students could be expected to be slow. Teachers generally felt that a teacher should reduce some priority goals for low performing students and that not all students can master priority objectives.

In Table XIV it can be seen that the teachers had mixed feelings about whether they preferred whole class instruction or small groups. They generally agreed that small groups should be formed when needed; two teachers were uncertain. Most of the teachers agreed that a lesson should be re-taught until students show that they have learned it. Two teachers disagreed that this should be done. Attitudes were mixed as to whether basic skills acquisition should take precedence over other school activities, four agreed and two disagreed.

Parental involvement and home work policy were part of the Basic skills program. To determine the teacher attitudes about parental involvement, five questions were asked on the survey. The results are shown on Table XV. Generally, the teachers believed that teachers should give students homework and that parents should know their responsibilities for helping students learn. Teachers believed that building standards and procedures that involved parents should be developed and that parents should be made aware of those procedures. The staff also believed that teachers should provide parents with information and techniques for helping students learn. 
TABLE XIV

TEACHER ATTITUDES ABOUT ACTUAL INSTRUCTION

\begin{tabular}{lll}
\hline Statement & $\begin{array}{l}\text { Strongly } \\
\text { Agree }\end{array}$ Agree Uncertain Disagree Disagree \\
\hline
\end{tabular}

13. Thole-group Instruction to teach skills is preferable

15. Small groups should be formed when needed to make sure all students learn thoroughly

7. Teachers should reteach lesson content until students show they have learned it

1

3

14. Acquisition of basic skills should take precedence over other school activities
3 
TABLE XV

TEACHER ATTITUDES ABOUT PARENTAL INVOLVEMENT

\begin{tabular}{|c|c|c|c|c|c|}
\hline \multirow[t]{2}{*}{ Statement } & Strongly & & & & Strongly \\
\hline & Agree & Agree & Uncertain & Disagree & Disagree \\
\hline
\end{tabular}

8. Teachers should give students homework to help improve basic skills

1

3

2

19. Parents should know their responsibilities for helping students learn

3

3

3. Building standards and procedures for involving parents should be developed

2

3

1

4. Parents should be made aware of the building standards and procedures that involve parents 6

20. Staff members should provide parents with information and techniques for helping students learn 
The principal played an important role in the Basic Skills program. To determine teacher attitudes about the role of the administrator as an instructional leader, four questions were asked in the survey. Table XVI shows that the teachers all agreed that the leader should work with the staff to plan ways to bring up low areas as determined by the California Achievement Test. All but one teacher agreed that leaders should monitor and evaluate improvement changes according to criteria established with the staff. The teachers were mixed in their view of whether a leader should coordinate staff improvement efforts and keep track of student achievement data. All teachers except one believed that the leader should head up renewal efforts once a year.

In order to determine what the attitudes of the teachers were concerning the Clackamas Elementary Basic Skills Program, several questions were asked on the survey. As shown on Table XVII the teachers were uncertain about whether the Prescriptive Reading Inventory (PRI) revealed important information about student skills. They generally did not value the PRI worksheets as teaching tools. They did not think the PRI strand tests were an accurate measurement of skills mastered. Most of the teachers were in favor of recording pretest and posttest PRI results so that progress could be determined. Generally, the teachers did feel that the 
TABLE XVI

TEACHER ATTITUDES ABOUT PRINCIPAL INVOLVEMENT

\begin{tabular}{llll}
\hline Statement & $\begin{array}{l}\text { Strongly } \\
\text { Agree }\end{array}$ & Agree Uncertain Disagree & $\begin{array}{l}\text { Strongly } \\
\text { Disagree }\end{array}$ \\
\hline
\end{tabular}

5. Administrators should work with staff to plan ways to improve the academic weak areas of the students as determined by the California Achievement Test

9. Administrators should monitor and evaluate improvement changes according to criteria established with staff cooperation

10. Administrators should coordinate staff improvement efforts and continue keeping track of student achievement data to access progress toward goals

15. Administrators should once a year head up renewal efforts to keep improvements in tune with changing needs 
six-week grade level meetings did help them plan their lessons for the next six weeks. Teacher attitudes were mixed about whether the grade level meetings helped them monitor student progress, and half of the teachers stated that they would rather plan their own program and not meet in grade level meetings. More than half of the teachers wanted to plan with teachers at their own grade level without help from the administration. However, the majority of the teachers believed that involvement of the administration was not an unnecessary intrusion into their teaching practices. Four teachers out of six felt that it was important to teach test-taking skills so that the students would be familiar with tests, and the achievement test results would be a true measure of learning. Four teachers out of six did not feel that the Basic skills Program was an effective way to improve weak areas. A majority of them believed that if there was improvement of weak areas, it could be credited to the teachers own materials and not the Basic skills Materials. 
TABLE XVII

TEACHER ATTITUDES ABOUT THE BASIC SKILLS PROGRAM

\begin{tabular}{lll}
\hline Statement & $\begin{array}{l}\text { Strongly } \\
\text { Agree }\end{array} \quad$ Agree Uncertain Disagree Disagree \\
\hline
\end{tabular}

22. The Prescriptive Reading

Inventory (PRI) revealed

important information about

students skills

5

1

23. The PRI student worksheets that

were used to teach skills were

excellent teaching tools

2

4

24. The PRI strand test that measured if a skill was mastered was an accurate measurement

1

3

2

25. It was important to record student PRI pretest results and the PRI posttest results so that progress could be determined

26. Meeting every six weeks at grade level meetings helped me plan my lesson plans that would include work on weak academic areas

27. Meeting every six weeks at grade level meetings helped monitor pupil progress in relation to Basic Skills teaching objectives

23. Instead of grade level meetings I would rather plan my own program by myself that will teach to weak academic areas

29. Instead of grade level meetings I would rather plan with the teacher my grade level without help from administration 
TABLE XVII Continued

\begin{tabular}{llll}
\hline Statement & $\begin{array}{l}\text { Strongly } \\
\text { Agree }\end{array}$ & Agree Uncertain Disagree & $\begin{array}{l}\text { Strongly } \\
\text { Disagree }\end{array}$ \\
\hline
\end{tabular}

30. The involvement of administration in

the grade level meetings was an

unnecessary intrusion into my teaching

practices

15

31. It is important to teach test taking skills to students so that the achievement test results will be a measure of learning.

2

2

1

32. The Basic Skills Program was an effectlve way to improve weak areas

2

3

1

33. If there was improvement of weak areas, I believe that my own teacher materials are to be credited and not the Basic Skills materials

4

2 
Three questions were asked to determine teacher attitudes about the school environment during the Basic Skills program. The results are found in Table XVIII. Four out of the six teachers believed that teacher motivation was low during the implementation of the Basic skills Program. However, four out of six teachers felt that student motivation was high as they worked on Basic Skills Materials. Generally, the teachers felt that the students were rewarded for academic achievement and excellence in behavior.

\section{Teacher Participation in the Treatment}

\section{Program Measured by Time Spent}

The two sources of information used to determine the extent of teacher involvement in the treatment program were teacher responses on the survey as to how much time they spent per week working on treatment materials and by student recording sheets that the teachers filled out as they completed materials with students. Appendix D displays a copy of the student recording sheet.

The survey revealed that the fourth grade teachers estimated that they used the treatment materials one to one and one-half hours per week. Table XIX compares the teacher participation in treatment measured by time spent. Both teachers in grade four completed an average of two work sheets per week. The fifth grade results 
TABLE XVIII

TEACHER ATTITUDES ABOUT SCHOOL ENVIRONMENT

\begin{tabular}{|c|c|c|c|c|c|}
\hline \multirow[t]{2}{*}{ Statement } & Strongly & & & & Strongly \\
\hline & Agree & Agree & Uncertain & Disagree & Disagree \\
\hline
\end{tabular}

34. Teachers' motivation was high as they implemented the Basic Skills Program

2

4

35. Students' motivation was high as they went through the Basic Skills Program

4 1 1

36. Students were rewarded for academic achievement and for excellence in behavior 
TABLE XIX

\section{TEACHER PARTICIPATION IN THE TREATMENT \\ MEASURED BY TIME SPENT}

\begin{tabular}{|c|c|c|c|}
\hline Grade & Teacher & $\begin{array}{l}\text { Teacher Estimated } \\
\text { Time Spent } \\
\text { Per Week }\end{array}$ & $\begin{array}{l}\text { Teachers' student } \\
\text { Sheets Recorded } \\
\text { Per Week }\end{array}$ \\
\hline Fourth & $\begin{array}{l}\text { Teacher \#1 } \\
\text { Teacher \#2 }\end{array}$ & $\begin{array}{l}1 \text { hour } \\
11 / 2 \text { hours }\end{array}$ & $\begin{array}{l}2 \\
2.7\end{array}$ \\
\hline Fifth & $\begin{array}{l}\text { Teacher \#3 } \\
\text { Teacher \#4 }\end{array}$ & $\begin{array}{l}11 / 2 \text { hours } \\
2 \text { hours }\end{array}$ & $\begin{array}{l}1 \\
2.6\end{array}$ \\
\hline Sixth & $\begin{array}{l}\text { Teacher \#5 } \\
\text { Teacher \#6 }\end{array}$ & $\begin{array}{ll}1 & \text { hour } \\
2 & \text { hours }\end{array}$ & $\begin{array}{l}3.4 \\
3.2\end{array}$ \\
\hline
\end{tabular}

indicate that teacher 3 might not have recorded all the student-completed sheets as he speculated that he used one work sheet for $11 / 2$ hours. The sixth grade teachers seem to have spent the most time on the materials. They recorded more than three work sheets per week. The materials that the teachers recorded were reading work sheets that emphasized comprehension, recall of facts, identifying fact and opinion, identifying main idea and character analysis. Each teacher spent an average of one and a half hours on the extra ceading materials that were not previously included in the regular reading program. The work-recording sheets collaborate the estimated times spent on the program (except for teacher \#3) as it would take about one and a half hours a week to complete the amount of work recorded for each student. 


\section{Teacher Suggestions for Changes in Next Year's Program}

The last part of the survey asked the participants to give suggestions for the Basic Skills Program for the next year. The teachers were asked to write comments on several areas of the Basic Skills Program they had just finished. Their comments follow:

Question: How would you change the Basic Skills Program to improve weak areas next year?

Please comment on the following:

\section{Response:}

\section{PRI Materials:}

I honestly don't know

More complete instructions, better copies

Be sure all worksheets are well matched to the tests, direct correlation, materials must be checked for clear printing, some were not legible.

Many were hard to reproduce and read. More choice of materials, I used many of my own when PRI was not satisfactory

Better copies needed make sure what we received was what we needed.

We need at least one test booklet per student. Enough worksheets and tests per student.

\section{Grade Level Meetings:}

Good, they made you keep up with the expectations/goals

If all materials are ready at the beginning of the year, grade level meetings are not needed.

O.K. 
Decide and let me know

Needed more time to organize materials and to be sure the right booklet was reproduced for the post-test (this was a constant problem)

O.K.

Parent Involvement:

Inform the parents and share tests results with them. Let them know if child is having difficulty

O.K.

Unnecessary, could be kept informed

More parent involvement is needed

I'm not sure how to involve parents in this or if they. need to be

Does this really work

What Materials I Would Use to Teach Low Areas:

Depends on the subject?

I'm not sure I have time to cover more than my regular curriculum and the Basic skills as used this year

Anything I can find that will get the material to the student in a way they can understand it

Group and concentrate curriculum

I used many of the attractive Frank Schaffer materials for specific areas pertaining to weaknesses in my class.

I have many types of reading skill building materials to draw from

Involvement of the Administration:

O.K.

(Blank Space)

Organize and evaluate, help where needed 
Better plan for providing materials at proper place at proper time

Support with materials, see that all area ready for use at beginning of year.

Very helpful meeting with you and Ron. You two worked a great deal to implement the program, Thanks

\section{Monitoring Progress:}

Leave it the same, it worked well

Is this to be a part of a report card grade? If so, I would set up my own tracking device

O.K.

Tests

The class sheet to monitor each goal was easy to use and gave a quick picture of each student's progress

The notebooks and tracking sheets seemed to be satisfactory

Teaching Test Taking Skills:

I do feel this is necessary

Introduce those skills earlier in year and relate them more closely to all academic areas

O.K.

I have some materials; practice test for CAT is good too

A difficult question to answer 
CHAPTER V

GENERALIZATIONS, CONCLUSIONS AND RECOMMENDATIONS

This chapter will review the need for the establishment of an effective school improvement program and will summarize the study and the results of the study as generalized from the relationships established in Chapter IV. Limitations of the study will be presented and the Basic Skills Program will be compared with the Milwaukie RISE Project. Conclusions and recommendations will be presented at the culmination of the chapter.

\section{Need for Effective School Improvement Programs}

In recent years statistics have shown that it costs more to educate fewer students and the results, as measured in achievement test scores, are lower than in the past. For this reason educational leaders, the public, and the government are advocating reform in educational financing and in education itself.

Educators today are feeling the pressure from the taxpayers' dissatisfaction and from the government's negative appraisals of education. School districts are developing Effective school programs to partially answer 
the demand for change. Districts are using the Effective School Research to formulate programs that will improve the educational process. However, there still needs to be more research on how to implement the effective school characteristics. As districts and individual schools search for ways to implement their own effective school program, they would benefit from research that describes successful techniques as well as unsuccessful methods. The Basic Skills Program, Clackamas Elementary's effective school program, will add to the research that other educators can review when they are planning their own effective school programs.

\section{Study Reviewed}

The purpose of this study was to investigate and to determine the effectiveness of the Basic Skills Program. This was a program developed at Clackamas Elementary School that implemented many of the effective school characteristics along with analyzing low-achievemnet areas in the California Achievement Test and organizing an instructional program that taught to those low areas. This study compared achievement test results from the spring of 1982 for grades four, five, and six (approximately 140 students) with achievement test results from the Spring of 1983. The control group took the California Achievement Test the year before the treatment 
group during the Spring of 1981 they took the pretest, and in the Spring of 1982 they took the posttest.

The treatment to improve the low areas as determined by the California Achievement Test results of Spring, 1982, consisted of teachers administering extra work sheets that covered the deficient skills, a homework program, six week teacher grade level meetings to analyze progress and practice tests that helped teachers evaluate the student's acquisition of the skill taught.

\section{Comparability of the Treatment and Control Groups}

The treatment group in this study consisted of fourth, fifth, and sixth grade students at Clackamas Elementary during the 1982-83 school year. The control group consisted of fourth, fifth, and sixth grade student at Clackamas Elementary School during the 1982-83 school year. The results of the chi square on lunch and drop-out indicate that there was no difference between groups. The $\underline{t}$ test on pretest means indicated that there was no difference between treatment and control groups except in the fifth grade where there were two differences. These results would lead to the conclusion that the treatment and control groups were comparable and they did come from the same population.

\section{Statistical Analysis of the Study}

Two different statistical approaches were used to analyze the data from the study. Normal Curve 
Equivalents, NCE scores, were used for the statistical analysis. The three sub-scales (Reading Comprehension, Math Comprehension and Math Concepts) from the California Achievement Test were analyzed by using a factorial multivariant analysis of variance on the NCE change scores for the control and treatment groups. The multivariate statistical hypothesis was not rejected for interaction and grade level; it was rejected for the treatment main effect. The results from this test indicated that there was a significant effect. However, the significant effect was in favor of the control group and not the treatment group.

Following the rejection of the multivariate statistical hypothesis concerning treatment, a factorial analysis of variance was performed on each dependent variable. Only the treatment main effects were examined as the interaction and grade level effects were not rejected in the multivariate case and the treatment main effect was rejected. The statistical hypothesis that the NCE change score means of the two populations were equal was not rejected for reading comprehension $(p=.72)$ and math concept $(p=.10)$. The statistical hypothesis that the NCE change score means of the two populations are equal was rejected for math comprehension $(p=.001)$. The research hypothesis that the population which did not receive treatment would have greater positive NCE mean change score than would the 
population which received the treatment was accepted. The change scores for the control group on Math Comprehension were greater than the change scores for the treatment group.

Control Group Significant Results

Out of the eighteen $t$ tests on NCE scores within groups performed, six were significant, four for the control groups and two for the treatment groups. This data adds to the conclusion that the control group did better than the treatment group during the study.

\section{Confidence Intervals on Mean Scores}

With the exception of the sixth grade control group, all of the .95 confidence intervals around group means for math concepts included zero; for this group, the lower limit of the confidence intervals was above zero, indicating that the sixth grade group started the year at a higher level than the normed sixth grade sample and ended the year at the same level as the normed sixth grade.

\section{Conclusions}

After analyzing the statistical results, it can be conciuded that the treatment had no or negative effect on the students' achievement. Students tended to show greater growth in the control year than they did in the treatment year. The reasons for the treatment or program failure can be better understood by analyzing the teacher 
attitudes about the program, and the elements of effective schools, and by consideration of the limitations of the program.

\section{Teacher Involvement and Attitudes}

The teachers who were involved in the treatment program were given a survey in the spring of 1983, after the treatment was completed. The purpose of the survey was to assess the teacher attitudes and involvement in the treatment program and to evaluate the presence and use of effective school characteristics.

How Teachers' Attitudes Coincide with Known Attitudes of Teachers in Effective Schools

One of the variables found to be present in effective schools (Lieberman and Miller 1981) is a high degree of teachers subjective efficacy beliefs that they have the power to teach anyone no matter what kind of a background the student has come from or what ability the student has. These effective teachers have high expectation for their students and do not lower goals for low students. The survey results revealed that five of the six teachers who were involved in the study believed that students from low socio-economic backgrounds can be expected to perform at a low academic level. All of the teachers believed that measured progress of a student from a low socioeconomic background can be expected to be slow and that 
teachers should lower priority goals for certain lowperforming students. All teachers disagreed with the statement that teachers can teach all students and all students can master priority objectives. It can be deduced that the teachers in the study did not have a high sense of efficacy, since Clackamas Elementary School is considered to be a low socio-ecnomic school, rated 15 th in a high to low ranking of socio-economic scale of 18 North Clackamas Schools. This scale was developed by the North Clackamas School District and used property values and related taxes as the base for the scale.

Another variable effective school researchers have determined as effective (Edmonds 1978) is that whole group instruction is more effective and that small groups should be formed if some students need extra help learning the concept. The survey revealed that three of the six teachers did not believe that whole group instruction was a better way to teach even though all of the teachers taught the program materials to their whole group at one time. All of the teachers believed small groups should be formed when needed to make sure all students learn thoroughly.

Effective schools research also suggests that successful schools develop narrow goals (usually to improve low areas in reading and math) and then spend more time trying to achieve these goals. In the survey, all but one 
teacher felt that acquisition of basic skills should take precedence over other school activities. It would appear then that most of the teachers did believe in the effective school variable of having narrow goals in reading and math.

Researchers found that effective schools involve parents and have established homework programs (Edmonds, 1979, Brookover 1979). The teachers' survey results indicated that all teachers did believe that building standards and procedures for involving parents should be developed. All teachers felt that teachers should give students homework to help improve basic skills and that parents should know their responsibilities for helping students learn. All teachers believed that parents should be made aware of the building standards and procedures and that teachers should provide parents with information and techniques for helping students learn. It would appear that all teachers felt strongly about the importance of involving parents and that homework was essential.

The effective schools research emphasizes the importance of the school principal as an educational leader. The research indicates (Brookover, 1979) that principals should be involved with the curriculum inside the classrooms and should help staffs set narrow academic goals which the principal would help monitor. All of the teachers indicated in the survey that they agreed that the 
administration should work with staff to plan ways to improve the academic weak areas of students and also that the administrator should monitor and evaluate improvements according to criteria established with staff cooperation. All of the teachers believed that the administration should monitor and evaluate improvements according to criteria established with staff cooperation. All of the teachers believed that the administrator should coordinate staff improvements efforts and continue keeping track of student achievement data to assess progress towards goals. All but one staff member believed that administration should once a year instigate renewal efforts to keep improvements in tune with changing needs. The teachers seemed to believe strongly that the administrator should be involved with them in the classroom and should be an instructional leader. However, they thought that the administration's involvement in the six-week grade level planning meetings that were a part of the treatment program was an unnecessary intrusion into their teaching practices. This would indicate that in theory the involvement of the principal was interpreted as positive; conversely, when the principal actually did get involved, the involvement was not interpreted as positive. 
Do the Attitudes of Teachers Differ From Grade Level to Grade Level?

The answers on the survey seemed to indicate that there was no pattern that would separate one grade level from another in beliefs and involvement. The answers at all grade levels, fourth, fifth and sixth seemed to be clustered together so that no real differences could be recognized.

\section{Teachers' Attitudes About Using the Treatment Program}

The survey results indicated that the teachers' motivation was low as they implemented the program. However, all of the teachers except one felt that the students' motivation was high as they went through the program and that students were rewarded for their efforts. Only two of the six teachers agreed that the program was an effective way to improve weak achievement levels. Four of the six teachers believed that, if there was any improvement, it could be attributed to their own materials and not the specific program materials. Five of the teachers felt that the involvement of the administration in the grade level meetings was an unnecessary intrusion, even though five of the teachers felt the grade level meetings helped them plan their lesson plans that included work on weak academic areas. Four of the teachers would rather meet with teachers at their own grade levels, 
without help from the administration, to plan their curriculum. All six of the teachers agreed that the materials used in the program did not teach the skill they were supposed to and that the assessment materials were not an accurate measurement of student growth.

All of the teachers believed that the California Achievement Test should be analyzed so that weak academic areas of students can be identified. However, two of the teachers believed that programs should not be developed to improve these identified weak areas, possibly because these same two teachers felt that improving low areas on the California Achievement Test would not improve skills children need to improve. All but one teacher indicated they were uncertain if the California Achievement Test measures grade level expectations for their grade level. Teachers' Suggestions For Changes in Next Year's Program Teachers indicated on the write-in section of the survey that the biggest problem was the fact that the PRI materials used to teach to low achievement areas were not adequate. The copies of work sheets were of poor quality and hard to read and they needed better teacher's editions to help with scoring. The teachers all definitely felt that other materials should be found that would teach the needed skill more effectively. 
Only one teacher felt that the grade level meetings were not needed and that she would rather do her own planning with her partner teacher or by herself.

Five out of six teachers believed that parents needed to be more involved next year. Appendix $\mathrm{E}$ shows all of the suggestions the teachers made on how to improve the program next year.

\section{Limitations of the Study}

\section{Change Research}

In order that the results of the study might be better understood, it is necessary to relate the variables of the study to recent literature on innovation and change. In the case of the Clackamas Elementary study, the culmination of effective school variables and the Basic skills curriculum program that was implemented did not result in significant student achievement. Purkey and Smith (1982) cautioned administrators that the effective school variables could not be used as a recipe for an effective school. In many ways, the Basic Skills program at Clackamas Elementary was implemented as if the changes were a recipe that could be instigated without consideration of known organizational factors and how these relate to decision making and implementation of an innovation. In the writers' opinion this constitutes the greatest weakness of the Basic skills program and explains why the program did not show significant growth in achievement. 
Description of the Clackamas Elementary as an Organization. Weick (1976) wrote that the school consists of a "loosely coupled" system. It is loosely coupled because there is very little influence or connection between administrators and teachers. This description depicts the environment of Clackamas Elementary very accurately. For many years, the teachers had been left to design their own programs without intervention from administration as shown by the fact that there were no curriculum inservice programs coupled with the evaluation process. Behind the closed doors of the classroom, the teachers were autonomous.

Rutter (1979) and Brookover (1979) referred to schools as cultures, each school culture formulated by people's attitudes and values in the school. In order for change to occur in this environment, attitudes and values have to change. According to the teacher survey that was given to the teachers at the end of the Basic Skills year long program, the teachers' attitudes and values did not coincide with the basic premise of the Basic Skills program. The Basic Skills program was developed from the philosophy that achievement test scores should be analyzed and a program developed to improve the schools. Four of the six teachers were uncertain and one teacher disagreed that bringing up low areas of the California Achievement would bring up skills that children needed to improve. 
Four teachers were uncertain and one disagreed that the California Achievement Test tested grade level expectations for their grade level. Four teachers agreed that some program should be developed to improve weak areas from the California Achievement Test and two teachers disagreed that that program should be developed. This lack of commitment on the part of the teachers for the basic skills program may have contributed to the failure of the program.

Firestone (1980) describes schools as being made up of many different images. Clackamas Elementary for years had been a "legislative" school, an open system where decisions are made by consensus. The Basic skills program was initiated by asking for input from every staff member as to how they would like to improve low areas in their classrooms. A few minor suggestions were made that would not have had much impact on the school program. The committee consisted of the Learning specialist, the vice principal and the principal, all well-informed on effective school research and anxious to apply the variables of an effective school to the Basic Skills program. With this knowledge and the minimal input from the staff, the committee formulated the program. The committee presented the plan to the staff during the spring of 1982, and indicated that the plan would begin the next Fall 1983. The staff accepted the plan without comment. At this 
point, the school image had changed from that of a legislative school to that of a bureaucratic school where the decisions are made from the top and the people have little say in the decisions. The plan was accepted by the staff at the presentation meeting in the spring of 1982 . However, the staff had no background of effective school research and didn't realize how the plan would actually affect them and their teaching in the classroom.

Theory of change. Lieberman and Miller (1981) wrote that in order for change to be successful, the culture has to change, and the change has to be linked with real concerns of the people involved. The Basic Skills program to improve weak areas as determined by Achievement Tests was not developmentally linked with teachers' concerns. The motivating force behind the program came from the district office which mandated that each school develop a program to improve test scores and from the Basic Skills committee which had knowledge of effective school variables. Lieberman and Miller (1981) theorize that change is successful because leadership recognizes the importance of concrete and symbolic support of teachers and the motivating force of a teacher's sense of efficacy in the classroom. The staff at Clackamas Elementary might not have been motivated to attempt the task of improving test scores as the teacher survey indicated that teachers did not have a high sense of efficacy in the classroom. Two 
of the six teachers were uncertain, three disagreed and one strongly disagreed that a teacher could teach all students and that all students could master priority objectives. Two teachers agreed that students from a low socio-economic background can be expected to perform at a low academic level and four disagreed. Five teachers agreed that teachers should reduce some priority goals for certain low performing students, and one teacher strongly disagreed. Generally, the teachers believed that they didn't have much effect on student progress because all students cannot reach priority goals, and those priority goals should be lowered for certain students. The seemingly limited sense of efficacy in the classroom coupled with the doubt that bringing up test scores from the California Achievement test would improve skills children need to improve, suggests that the teachers may not have been concerned enough about the problem to initiate change.

Gross (1971) wrote that a "decision to change is only a proposal to change" (p. 214). For a real change to take pace, there has to be a "mutual adaptation" which refers to an innovation that has changed as well as the people who are involved in the change. The people and innovation adapt and the change is incorporated. In the case of the Basic Skills Program, "Cooptation" apparently occurred with the participants indifferent to and resisting change, and the change was incorporated into the 
system anyway. This was a one-way process where the participants did not practice the change because they did not value the change and the program was not developed out of their own concerns. In the teacher survey, four teachers agreed and two were uncertain about the statement that "if there was improvement of weak areas, I believe that my own teacher materials are to be credited and not the Basic skills materials." Three teachers were uncertain, two disagreed and two agreed that the Basic Skills Program was an effective way to improve weak areas. All teachers disagreed that the basic skills materials were excellent teaching tools. Five of the teachers would rather have planned with the teachers at the same grade level without help from the administration. This data suggests that the program was mandated by the administration or committee and the teachers did not like the format of the program.

That teachers wished to preserve their autonomy was indicated by their agreement with the statement that they wanted to plan without help from administration. The Basic Skills program interfered with teacher autonomy because grade level meetings where held where in the vice-principal and principal helped teachers monitor students' progress and determined what work sheets to use when teaching a specific skill. 
The federal government found that generally the RDDA (Research, Development, Diffusion and Adoption) model resulted in cooptation of the innovation, where the innovation was incorporated into the system but the people did not change their behavior and accept the change. The reason for the failure is parallel to why the Basic skills model ended in cooptation, the innovation did not consider the people who were to be involved in the innovation.

Hall and Alford (1976) also refer to the importance of the change becoming a felt need of the people involved, established in the first of the three steps of their Innovative Process (awareness, information, and personal management). The next stage, that of initiation, should develop from the felt need that the initiation stage involves group concensus that has been established in the first three steps. In the third stages they stress the importance of assistance in the classroom given by a consultant. The Basic Skills program did not allow for a change agent that would serve as a linking agent to help teachers in the classroom with actual instruction. The linking agent could have helped with search and retrieval and with application for the purpose of achieving "essential change" where the change is voluntary. Resistance to change. Many times change will appear to be accepted by the participants involved until the innovation gets to the implementation level. It was not 
until the teachers were actually having to implement the Basic Skills materials into their classroom did they start to speak out against the program. When they had to change their behavior, they started to make comments Iike, "I'm not sure I have the time to cover more than my regular curriculum and Basic Skills." "If all materials are ready at the beginning of the year, grade level meetings are not needed," and "Does this really work?"

Researchers have given many reasons for the resistance to change that can be applied to the staff involved in the Basic Skills Program. First, the Rand Corporation found that the older (over 40 ) teacher is less likely to adapt to change. The older teacher is more reluctant to change because he/she has developed outside interests that take priority over improving his/her professional position. Of the six teachers involved in the Basic skills program, five were over 40 and had been teaching more than 20 years. One teacher had taught two years and was twenty-six. The majority of these teachers had developed outside interests, ranging from raising and selling quarter horses, to participating in a half-time army career, to involvement with teenage children demanding a lot of time.

Hanson (1979) wrote that resistance also comes because people do not want to disturb the status of their informal social groups within the system. A developed 
informal social tradition had been established at Clackamas Elementary that started off each morning with coffee in the teachers' room and continued into the hall with the teachers leaning for about fifteen minutes against the heater while the students arrived at school. The socializing that this routine allowed was valued by the teachers, and when grade level meetings for preparation of basic skills materials interfered with this social routine, complaints of too many meetings were heard. Hanson (1979) also stated that if a person is upwardly mobile he/she will be more open to change. Only one of the six teachers had any desire to go into administration or move up in the system.

Goodlad (1975) wrote that an indicator of a person's ability to change is the person's interest and particiation in out-of-town educational meetings. None of these teachers was interested in going to an out of town meeting that was offered to the whole staff during the Basic Skills treatment year.

Firestone (1980) stated that teachers have a lack of knowledge and have no system for sharing knowledge. If teachers are to resist change, they will do it by noncompliance, or will openly confront authority, or they will be passive and not implement the change. All three of these indicators of resistance to change occurred in the Basic Skills program. After three weeks of the 
program the teachers stated that they didn't understand the program and how it was supposed to work. The committee developed a notebook for each teacher and took them through each step of the process, writing each step out.

The teachers, through consistant lack of understanding, managed to hand more and more of the responsibilities of the program back to the administration. This non-compliance was a form of passive resistance as they made very little effort to understand the program on their own.

At one point during the year, a representative from the staff was sent to confront the vice-principal about the homework program that was in the process of being developed. The representative had personally gone around to each teacher to obtain information and then delegated himself representative of the whole group. This teacher, who spent so much effort gathering data from the teachers for the purpose of open confrontation, was the same teacher who said he couldn't teach the program because he didn't understand the process and needed each step written down. This behind-the-scenes manipulation for change is what Hanson (1979) refers to as the "Guerrilla" change agent. This change agent is a person from within the system who has established small groups of support. He/she moves quietly and does not usually have an official 
title. The Guerrilla change agent in this case did arrange for change because a group meeting was called and the participants had a chance to air their views and concerns about the Basic Skills Program.

The main goal of the change agent should be to maintain the present system while changing it to perform better (Havelock, The Change Agents Guide 1973). The main change agent in the Basic Skills Program was the vice-principal, a woman who had been a first-grade teacher in the school the year before. Havelock (1973) empahsizes the importance of establishing a trust relationship between the change agent and the people involved. For trust to be developed, a certain amount of time has to pass so that each group can get used to the new person in the new role. At Clackamas Elementary, time was not allowed for the vice-principal to develop a trust relationship with the staff in her new role as vice-principal. Planning for the Basic Skills program began before she was vice-principal when she was a member of the steering committee. The actual program began immediately in the Fall of her first year.

Hanson also stated that people will resist change if they do not like the person who suggests the change. In the case of the vice-principal, it might not have been a case of disliking her, but of mistrusting the motives for 
all of her suggestions for change. It was suggested several times throughout the year that they were guinea pigs for the vice-principal's doctoral dissertation. It was also implied that the Basic Skills program was a stepping stone for the vice-principal who wanted to become a principal.

Implementation of change. The resistance to change in the Basic Skills program was heightened because not enough time was allowed for each participant to go through each individual level of change. Hersey and Blanchard (1969) state that first, a person has to have knowledge of the change issues. This knowledge will cause a personal attitude to change so that at the next step a change in behavior will occur. When each individual in the organization has realized the need for change, has decided to change and actually has changed behavior, then the organization will be changed. In the Basic Skills program little time was given to recognize the need for change, and time was not allowed for attitudes to change.

Hall and Loucks (Journal of Teacher Education, 1975, pp. 52-56) described the levels an innovation can go through. The Basic Skills program went through five of the nine levels. The program passed through the orientation levels where people become aware, the preparation level where people prepare to use, the mechanical use where people use the program but methods are not refined, 
and the routine level where people use the innovation but there is no attempt to revise and make it better. The participants in the Basic Skills program never went on to refinement (people revise change so that it is more effective for the user) to integration (people practice innovation changing as they proceed), or to revising (people talk with each other to make the whole program better), and finally to renewal (the older program is revised and put into effect). Therefore, the Basic Skills program did not progress through all of the levels of an innovation and thus the innovation was incomplete.

Comparison of Basic Skills Program With Milwaukie RISE Project

Purkey and Smith (1982), combine the organization-structure characteristics of effective school with the process--form characteristics and develop a portrait of an effective school. This portrait can be used to evaluate other studies. In the Milwaukie RISE Project McCormack and Kritek, (1982) and the in the Clackamas Elementary School Basic Skills Program, the organizational and structural variables were set into place by the administration or by bureauratic means. Both programs developed the variables of: school-site management (each building had autonomy to address problems); strong leadership from the principal, curriculum focused 
on skills that needed to be learned and the effort was coordinated across grade levels; parents were informed of school goals and student responsibilities especially with regard to homework, school-wide recognition of academic success in the form of ceremonies, symbols and accomplishments officially recognized; and district support. Two remaining variables in the organizational and structural variables were present in the Milwaukie RISE Project but not to a great extent in the Clackamas Basic Skills Project. They were the maximized learning time where there is a concentrated effort to develop class periods that are free from interruptions, and the area of staff development that involves changing people's attitudes and behaviors as well as providing them with new skills and techniques. The absence of two of the organizational-structural characteristics that Purkey and Smith say are essential for an effective school might explain in part why the Basic Skills Program did not produce significant results and the Milwaukie RISE project did produce greater gains than expected.

Of the Purkey and Smith's process-form variables, three of the four variables were present in the clackamas Basic Skills program and all four were present in the Milwaukie RISE Project. Both the Basic Skills program and the Milwaukie RISE project developed clear goals and high expectations and continually monitored individual pupil 
progress, order and discipline to maintain a serious purposeful atmosphere, and a high sense of community through use of ceremony, symbols, and rules. The variable that directly concerns process planning that incorporates collaborative planning and collegial relationship was present in the Milwaukie RISE project but not in the Clackamas Basic Skills program. The Basic Skills project seemed to allow for consensus of staff but really most of the decisions were made by the administration and mandated to the teachers. This tended to divide the staff and administration and limit intellectual sharing that can lead to consensus that promotes feelings of unified commonality among the staff. It is the absence of this process-form variable that added to the failure of the total Basic skills Program.

\section{Conclusions and Recommendations}

The thesis of this study was that a planned curriculum program combined with variables proven to be present in effective schools would produce greater gain in achievement than would be attainable with normal maturation. The interfacing of effective school characteristics and curriculum programs targeted as low academic areas has proven successful in other districts such as in the Milwaukie RISE Project. However, in the Basic Skills Program at Clackamas Elementary, the growth the students made 
was not significant, even though many effective school variables were present and a special curriculum was developed to improve low areas. The failure of the Basic Skills project can be attributed partially to the fact that the administrators in charge mandated the changes to the staff and incorporated the new program as if it were a recipe that could be given without modification and input from the people involved. The administrators needed to deal with important issues such as: how to get commitment of the staff for the program by using the problem-solving method; how to inservice staff about effective school variables that would develop a learning environment where teachers believe that children can learn and they, the teachers, have the power to teach and make a difference; how to use a linking agent that would help teachers in the classroom; how to heighten professionalism in teachers; and how to give enough time to implementation to allow for people to pass through different levels of implementation.

\section{Problem Solving Method to Develop Commitment}

The goal of a change effort in a school environment should be "mutual adaptation" where the innovation and the people's attitudes change and unite due to the process of a problem solving method used to develop the change. Hansen (1979) suggests a model for change that should be used in unison with Hall and Loucks (1975) levels of 
concern that occur within the individual. The change process begins with participants recognizing the need for change. The personal level of awareness should be developed by an administrator wanting to make change. In the case of an academic improvement plan, the teacher should study test scores and determine low areas. Committees should research what other districts in other parts of the country are doing to improve scores. Papers ilise the "Nation At Risk Report" (1983) should be discussed by the faculty so that they can become aware of what people all over the nation are saying about education. Teachers should compare school's achievement test scores with other schools in their own district and throughout the United States. After the awareness has been developed, the staff can reach a consensus that a program should be developed to do something about the problem. The instructional leader (the principal) should guide the staff in developing a problem statement that defines the problem in narrow terms, so that the outcomes can be measured easily in terms the problem and its subsequent diagnosis as stated in the very beginning. The diagnosis involves the staff in pinpointing what areas need to be worked on. The next step is research and retrieval where the staff or a subcommittee investigates different alternatives and materials that can be used. In this stage, as in the awareness stage, time is an important issue. Enough time 
must be allowed so that the staff can have inservice on effective school research, different curriculum programs that they could use, consultants that could be used, and visits to other schools to see new programs, or go to workshops that will give them ideas. When the staff is satisfied with their research and retrieval, they then will be ready to select a program of innovation that includes materials they feel would be effective. At the personal level, this is where each teacher has to begin to visualize how the change will personally effect him/her in the classroom. They have to plan how to implement the change and imagine the outcome after the innovation has been practiced. The teachers at this level also need to value the change, and develop ownership and commitment for the change. If the teachers have been given enough time to see the need for the change and if they have had significant input in the development of the change program, then the commitment should have been developed. This concept of teacher commitment for the change is paramount to the total change process because if the teachers do not value the change, they will resist the change. At the time the staff plans the innovation, they should also plan an ongoing inservice that will interface with the innovation. They should select a change agent whom they respect to carry out the inservice and to help individual teachers in their classrooms. 
The next stage is the actual try out of the innovation. At first, the innovation is practiced by the teachers at a mechanical level. Hall and Loucks (1975) describe their levels of innovation and suggest that after mechanical use comes a routine use where people use the innovation but there is no attempt to revise or make it better. An administrator should be aware that many times this routine stage is as far as some innovations develop. If more time to meet and refine and revise is not planned for in the total program, the program or change will not be modified by the teachers to better fit their needs. Teachers need time to talk with each other about changes and time to practice those changes, and then time to revise again. Hall and Loucks also suggest that an individual needs to collaborate with others for the purpose of making the innovation better in order to pass through another level of concern that occurs in an inservice program. It is at this stage of practice and refinement that the change agent can provide help for the individual teacher who might be having trouble adapting the change to his/her classroom. Purkey (1982) suggests that staff development should be on an individual basis so that the problems that each teacher faces with can be dealt with. In the final stage, an evaluation of the program should be carried out. The origiral goals should be compared with the outcome of the program. Plans for revision 
should be made which will be the change force for the newly developed program. At the personal level of concern, the evaluation serves as a reinforcement to the individual teacher. Receiving feedback about the efforts made is a positive conclusion to a change effort and revising the program to take care of any negative factors helps develop a feeling of efficacy, the developed feeling of a teacher's ability to control the learning environment.

\section{The Linking Agent and Inservice}

The importance of a linking agent in the change effort or inservice program is emphasized by Joyce and Showers (1980). They write that most inservice programs consist of a presentation of theory, describing a skill or strategy, modeling of the skills and usually some practice in a simulated or classroom setting. They warn that most inservice does not result in teacher behavior change because the inservice efforts stop at the practice level. They suggest that all inservice programs need to have a provision for information about performance in the form of a hands-on classroom assistance and coaching situations. They write that direct coaching on how to apply the new skills and modeling is a necessity if improvement through inservice training is to be acomplished. It is also important that the participants plan the inservice themselves and select the change agent. If this self- 
selection occurs, the participants will be more committed and will tend to value the inservice training.

Changing Attitudes and Motivation

Hansen (1979) writes that essential change is voluntary change. The key factor in voluntary change is that the people feel a need and want to change. Guba (1974) writes that people can be convinced of a need by several techniques. In the awareness stage of a proposed innovation appealing to teachers' values (it will be good for kids) or using rationale like it will be good for the school tends to help motivate teachers to change. Concerns about the motivation like, "the change cannot take place because no one is trained," should be answered with ideas of inservice training. Psychologically, people need to know that they will have a say in how the change will take place and what the change will be. Lewis (1980) suggests that peple aren't as motivated to change for monetary reasons as they are for a heightened feeling of professionalism, recognition for doing something, access to resources, people, materials, being pulled out of regular job to work on problems, sharing with others what they are doing and added responsibility. Teachers can be influenced to change because of political factors or compelled to change because of use of authority. These last two forces for change do not develop a heightened commitment to the change as do the other incentives mentioned. 


\section{Finale}

The Basic Skills Program was not successful. However, the data collected from the program could be used as a source of information for other schools involved in development of their own programs. A program to improve skills should provide for: 1) consensus decision making, 2) time for participants to grow to value the program, so they will actually use the new procedures, 3) time for reevaluation of the program as the program is in progress, so that the program can change to meet human needs, 4) inservice training that extends into the classroom so that teachers have support during the change, and 5) rewards and payoffs for the participants. The teaching materials that are being used in a program should be easy for teachers to use, should be geared to ability levels and directly related to the skill that needs to be taught. Change is possible with these considerations but if elements are left out, as was the case in the Clackamas Elementary Basic Skills Program, the change will not occur. 


\section{REFERENCES}

A\&T Associates' Study of the Research and Development Utilization (RDU) Program, City Menlo Park, California: Stanford Research Institute, 1980 and 1981

Arenas, S. "Innovations in Bilingual/Multicultural Curriculum Development." Children Today, May-June $1980,17-19$.

Armor, D., et al. Analysis of the School Preferred Reading Program in Selected Los Angeles Minority Schools, Santa Monida, Calif: Rand Corporation, 1976 .

Austin, G. "Exemplary School and the Search for Effectiveness." Education Leadership, October 1979, 10-14.

Averich, H.A. et al. How Effective is Schooling? A Critical Review and Synthesis of Research Findings, Santa Monica, CA: Rands, 1972.

Bailey, w. "Improving Instruction Through Research-Based Staff Development." Educational Technology, Sept. $1980,41-42$.

Bennett, C. "A Case for Pluralism in the schools." Phi Delta Kappan, April 1981, 589-592.

Berman, P. and McLaughlin, M.; Federal Programs Supporting Change, Volume IV: the Findings In Review. Santa Monia, California: Rand Corporation, 1977.

Bidwell, C. E. "The School as a Formal Organization." In March, J. (ed.), Handbook of Organizations. Chicago, Ill.: Rand-McNally, 1965.

Blau, P. "Structural Effects" American Sociological Review XXV April 1976, 178-93.

Brookover, W. "Elementary School Social Climate andSchool Achievement." American Educational Research Journal, Spring 1978, Vol. 15, No. 2, 301-318. 
Brookover, W. B. et al. School Social Systems and Student Achievement: Schools Can Make a Difference. New York, N.Y.: Praeger Publishers, 1979 (First published 1977 under title, Schools Can Make A Difference).

Brookover, W. B. \& Lesotte, L. W. Changes in School Characteristics Coincident with Changes in Student Achievement. East Lansing, Mich.: Institute for Research on Teaching, College of Education, Michigan State University, 1979 (Ed 181 005).

Brookover, W. B. \& Schneider, J. M. "Academic Environments and Elementary School Achievement." Journal of Reserch and Development in Education, Vol.9, No. 1, 1975, 82-91.

Brophy, J. "Teacher Behavior and Student Learning." Educational Leadership, October 1979, 33-38.

Brophy, J.E. and Good, T. "Teachers' Communication ofDifferential Expectations for Children's Performance: Some Behavioral Data"; Journal of Educational Psychology, 61, 1970, 365-374.

Burger, W. Financing Public Education in Oregon, Foundation for Oregon Reserch \& Education, April 1982, $1-2$.

Chase, F. "The Regeneration of Public Education inOur Cities." Phi Delta Kappan, January 1979, 353-356.

Clark, David. "Factors Associated With Success in Urban Elementary Schools." Phil Delta Kappan, March 1980, $467-470$.

Clune, W. H. Smith and Purky Personal Corespondence. Madison, Wis.: University of Wisconsin-Madison, 1982 .

Coleman, J.S. et al. Equality of Educational Opportunity. Washington D.C.: Government Printing Office, 1966

Coleman, J.S. et al. Public and Private schools (draft). Chicago, Ill.: National Opinion Research Center. University of Chicago. 1981.

Cross, Ray. "What Makes An Effective Principal?" Principal, March 1981, 19-22. 
Deal, T. "How Much Influence Do (and Can)Educational Administrators Have on Classrooms?" Phi Delta Kappan, March 1980, 471-473.

Deal, T. E. et al The Early Childhood Education Program: An Assessment of Its Impact and Implementation. Sacramento, Caifornia: California State Department of Education, May 1977.

Derr, C. B., \& Deal, T. E. "Toward a Contingency Theory of Change in Education: Organizational structure, Processes, and Symbolism." In King, E. (ed.) Education for Uncertainty, London: SAGE Publications, 1979.

Dornbush, S. M., \& Scott, W. R. Evaluation and the Exercise of Authority. San Francisco, CA: Jossey-Bass, 1975 .

Dreeban, R. "The School as a Workplace." In Travers, R. (ed.), Second Handbook of Research on Teaching. Chicago, Ill.: Rand-McNally, 1973.

Edmonds, R. R. "Effective Schools for th Urban Poor." Educational Leadership, October 1979, 15-17.

Edmonds, R. R. \& Frederiksen, J. R. Search for Effective Schools: the Identification and Analysis of City Schools that are Instructionally Effective for Poor Children, ED $179396,1979$.

Edmonds, R. R. "Some Schools Work and More Can." Social Policy, Vol. 9, 1979(b), 28-32.

Edmonds, R. R. "A Report on the Research Project, 'Search for Effective Schools...' and Certain of the Designs for School Improvement tha are Associated with the Project." East Lansing, Mich.: the Institute for kesearch on Teaching, College of Education, Michigan State University, Unpublished report prepared for N.I.E., 1981.

Firestone, W. A. "Images of Schools and Patterns of Change", American Journal of Education, August 1980, 459-485.

Fisher, C. N. et al. "Teaching Behaviors, Academic Learning Time, and Student Achievement: An Overview," In Denham, C. and Iieberman, A. (eds.) Time to Learn: Washington, D.C., U.S. Department of Education, May 1980 . 
Glazer, N. "Ethnicity and Education: Some Hard Questions." Phi Delta Kappan, January 1981, 386-389.

Good, T. L. "Teaching Effects: A Process-Product Study in Fourth-Grade Mathematics Classrooms." Journal of Teacher Education, 28, 1977, 49-54.

Goodlad, J.I., A Place Called School, New York: McGrawHill, October 1983 .

Goodlad, J.I., The Dynamics of Educational Change. New York: Mc Graw Hill, 1975 .

Gross, N., et al, "Implementing Organizational Innovations," (New York: Basic Books, 1971), p. 214.

Guba, E. G. "Research in Internal Administration-What Do You Know?" Administration Theory As A Guide to Action, 1974, 113-130.

Hall, D. and Alfred, S.; Evaluation of theNational Diffusion Network, Menlo Park, Califoria: Stanford Research Institute, January, 1976.

Ha11, G. Loucks, S. "Level of Use of the Innovation Framework for Analyzation of Innovation Adaptation," Journal of Teacher Education, Spring 1975, 52-56.

Halpin, A. W., \& Croft, D.B. The Organizational Climate of Schools. Midwest Administration center, University of Chicago, 1963.

Hansen, M. E. Educational Administration and Organizational Behavior, June 1979, 298-361.

Hargrove, E. C. et al. Regulations and Schools: the Implementation of Equal Education for Handicapped Chilaren. Nashville, Ten.: Institute for Public Policy Studies, Vanderbilt University 1981.

Havelock, R. The Change Agent's Guide to Innovaton in Education, New Jersey: Educatonal Technology Publications, 1973, 13-14.

Heisner. "The Urban Schools: There Are Success Stories." Instructor, January $1981,18$.

Hersey, P. \& Blanchard, $K$, Management and Organizational Behavior: Utilizing Human Resources, Englewood Cliffs, Prentice Hall, New Jersey, 1969. 
Hersh, R. H. et al. "The Management of Educational Professionals in Instructionally Effective Schools: Towards the Research Agenda" Unpublished paper. Eugene, Oregon: Center for Educational Policy and Management, University of Oregon, 1981.

Itzkoff, S. "Minorities: Cultural Pluralism in Urban Education." School and Society, Nov. 1966, 383-386.

Jencks, C. S. et al. Inequality: A Reassessment of the Effect of Family and Schooling in America. New York, N.Y. Basic Books, Inc., 1972.

Johnson, E. "The Curriculum: Status Quo. ForesightVol. 1, Number 4, October 1982.

Jones, C. "An Introduction to the Study of Public Policy." Dusbury Press, 1977.

Joyce, \& Showers, "Improving Inservice Training: Messages From Research," Educational Leadership, February $1980,380-385$.

Klitgaard, R. E. \& Hall, G.R. "Are There Unusually Effective Schools" Journal of Human Resources, Vol 10 , No. $1,1974,90-106$.

Levine, D. \& Stark, J. Extended Summary and Conclusions: Institutional and organizational Arrangements and Processes for Improving Academic Achievement at Inner City Elementary Schools. (mimeo) Kansas City, Mo.: University of Missouri-Kansas City, School of Education, Center for the study of Metropolitan Problems in Education, August 1981.

Lewin, K. "Frontiers In Group Dynamics," Human Relations (1974); Field Theory In Science New York, Harper and Row, 1951 .

Lewis, K. S., et al; A Study of the R \& D Utilization Program, National Institute of Education's Program on Dissemination and Improvement of Practice, Washington, D. C. 20208-1100, 1980.

Lezotte, L. W. et al A Final Report: Remedy for School Failure to Equitably Deliver Basic School Skills, East Lansing, Mich.: Dept. of Urban and Metropolitan Studies, Michigan State University, Sept. 1977. 
Lieberman, A. \& Miller, L. "Synthesis of Research in Improving Schools." Educational Leadership, April $1981,583-586$.

Lieberman, A. "Suggestion Let's Stamp Out Innovations" School Board Journal. January 1980, 27.

Little, J. W. "School Success and Staff Development in Urban Desegregated Schools: A Summary of Recently Completed Research." Boulder, Col.: Center for Action Reserach, Inc., Paper presented at the Annual Meeting of AERA, Los Angeles, April 1981.

Lortie, D. C. School Teacher. Chicago, IIl.: University of Chicago Press, 1975.

Madden, S. V. et al., School Effective Study. Unpublished Manuscript, State of California Dept. of Ed. , 1976.

March, J. G. \& Olsen, J. P. Ambiguity and Choice in Organizations, Bergan: Universitetsforlaget, 1976.

McCormack, L. M. and Kritek, "Milwaukee's Project RISE,:" Educational Leadership. December, 1982, 16-21.

McCormick, W. "Teachers Can Learn to Teach More Effectively." Educational Leadership, October 1979, $59-60$.

McLaughlin, M. W. "Implementation as Mutual Adaptation: Change in Classroom Organization." In Mann, D. (ed.), Making Change Happen, New York, N.Y.: Teacher's College Press, 1978.

Meyers, J. W. \& Rowan, B. "The structure of Educational Organizations." In Meyer, M. et al (eds), Environment and Organizations, San Francisco, Cal.: Jossey-Bass, 1978 .

Miles, M. "On Temporary Systems," Innovation in Education, Matthew Miles Ed, New York: Teachers College press, 1964,443 .

Murname, R. J. "Intepreting the Evidence on School Effectiveness" Working paper No. 830. New Haven, Conn.: Institution for Social and Policy Studies, Yale University, December 1980.

National Commission on Excellence in Education, A Nation At Risk: the Imperative for Educational Reform, U.S. Dept. of Education, Wash. D.C., April 1983. 
Network Inc., The Analysis of 63 Innovative Projects and 3 Alternate Dissemination Strategies. (NDN, Title IV-C, Market Linkage) 1981; 1982.

Newmann, F. M. Reducing Alientation in High Schools: Implications of Theory." Havard Educational Review, Vol. 51, No. 4, November 1981, 546-564.

Newton, B. "Theoretical Foundations for Cultural Pluralism in the Curriculum." The Urban Review, Vol. 12, no. 1. 1980 .

New York State Department of Education, Reading Achievement Related to Educational and Environment Conditions in 12 New York City Elementary Schools, Albany, N.Y.: Division of Education Evaluation, March 1974.

New York State Department of Education, School Factors InEluencing Reading Achievement: A Case of Two Inner City Schools. Albany, N.Y. Office of Education Performance Review, 1974 (Ed 089 211)

New York State Department of Education, Three Strategies for Studying the Effects of Schools Processes. Albany, N.Y.: Bureau of School Programs Evaluation, March 1976.

Peterson, P. "Direct Instruction: Effective for What and for Whom?" Educational Leadership, October $1979), 46-48$.

Pettigrew, T. "Racially Separate or Together?" Cultural Pluralism, Edgar Epps, McCutchan Publishing Corporation, Berkeley, California 1974.

Pickhardt, C. E. "The Truth is, You Can Proivde Leadership by Resisting Change." The American School Board Journal, February $1979,36-37$.

Popkewitz, T. S. "Educatonal Reform As the Organization of Ritual: Stability as Change," Journal of Education, 1981, 1-29.

Purkey, S. \& Smith, M. "Effective Schools--A Review." Wisconsin Center for Education ResearchSchool of Education, University of Wisconsin at Madison, June, 1982 .

Rutter, M. "School Effects on Pupil Progress: Research Findings and Policy Implications." Paper prepared for National Institute of Education, U.S. Department of Education, February 1981, 26-28. 
Rutter, M. et al Fifteen Thousan Hours: Secondary Schools and their Effect on Children. Cambridge, Mass.: Harvard University Press, 1979.

Scott, R. "Schools Alone Are Insufficient: A Reponse to Edmonds." Educational Leadership, October 1979, 24-25.

Spartz, J. L. et al. Delaware Educational Accountaiblity System Case Studies: Elementary School Grades 1-4, Dores, Delaware: Delaware Department of Public Instruction, 1977. .

Sweet, R. "Building For Tomorrow: A National Priority" Our Children's Education; A Time to Reform, The Foundation for Oregon Research and Education, February 1983, 12-17.

Venezky, R. L., Winfield, I. F. "Schools that Succeed Beyond Expectations in Reading." Studies in Education, Newark Delaware: University of. Delaware, (ED 177 484) 1979 .

Weber G., Inner City Children Can be Taught to Read: Four Successful Schools, Occasional Paper No. 18, Washington, D.C.: Council for Basic Education, 1971 .

Weick, K.E. "Educational Organizations as Loosely Coupled Systems" Administratie Science Quarterly 21, 1976, pp. 1-19.

Weischadle, David. "School-Based Management and the Principal." The Clearing House, October 1980.

White. B., "Critical Influences on Oregon of Competence" Merrill-Palmer Quarterly, 21(4): October 1975, $256-66$. 


\section{APPENDIX A \\ DEFINITION OF NCE SCORES FROM THE \\ CALIFORNIA ACHIEVEMENT TEST}




\section{DEFINITION OF NCE SCORES FROM THE}

\section{CALIFORNIA ACHIEVEMENT TEST}

NCEs (Normal Curve Equivalents) are the scores used to help evaluate the effectiveness of a program. NCE scores differ from percentile rank scores in that percentile rank compares a student's performance on a test with the performance of students in the norming sample for that test, yielding the percentage of norm group students who fell below a particular score. An NCE score also represents a student's level of achievement compared with students in the norm group, but using different units. To evaluate the effectiveness of a program the average scores of the students need to be determined so there is an average for the whole group. To do this NCE scores are used because they have equal intervals, and percentile scales are not equal. The NCE scale and the percentile scale are matched at the 1st, 50th, and 99th points. This can be seen in the figure below which presents a comparison of the two scales. Notice that the distance between

Percentiles

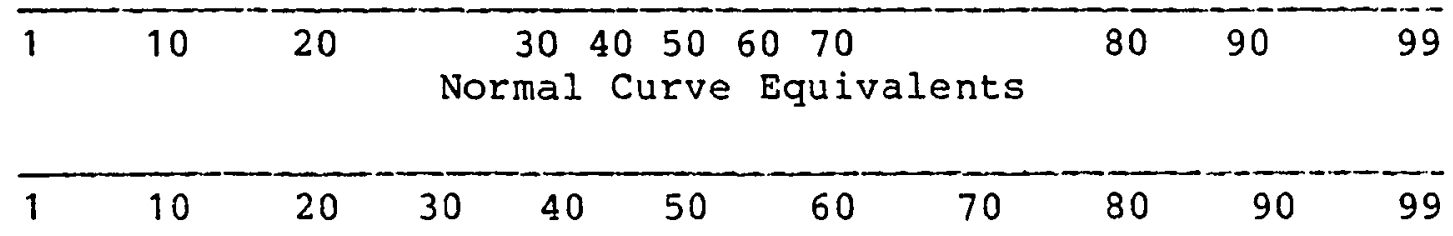


points on the percentile scale are not equal. At the upper and lower ends of the scale, the points are farther apart than at the middle of the scale. On the NCE scale, the distance between points are the same.

An advantage of NCEs over a standard score or expanded score is that NCEs mean the same thing regardless of the test used or the grade level. Expanded scores on the other hand, are not comparable from one test to another or from one grade to another.

In summary, NCEs have two primary advantages for program evaluation over other types of scores--they can be averaged and they are comparable across grade levels and across tests.

NCE GAIN SCORES

Usually students are pretested early in a program and posttested late in a program to determine how much they have grown in achievement. This growth is due to regular classroom instruction, maturation, and home influences as well as the supplementary program. On the average a student tends to remain at the same rank relative to his peers. Thus, a group of students whose pretest was at the 20th percentile. Any gain over the expected growth as determined by the ranking of the pretest is a gain that 
can be attributed to the supplementary program effectiveness. This gain is an indication that extra growth has occurred over and above the regular growth which would have been expected with only regular classroom instruction. If NCEs are used instead of percentiles the NCE gain for the group is the difference between the average NCE on the posttest and the average NCE on the pretest. It is considered that moderate gains are 5-10 NCEs and gains more than 20 NCEs are unusually high and may reflect errors in the way the evaluation was implemented. A gain of zero does not indicate "no growth at all." With a zero NCE gain, the achievement level has increased from pretest to posttest, but this increase in achievement level would have been expected with just regular classroom instruction. A negative gain indicates that students did not grow as much as students in other schools. 
APPENDIX B

CLACRAMAS ELEMENTARY BASIC SKILLS PROGRAM 


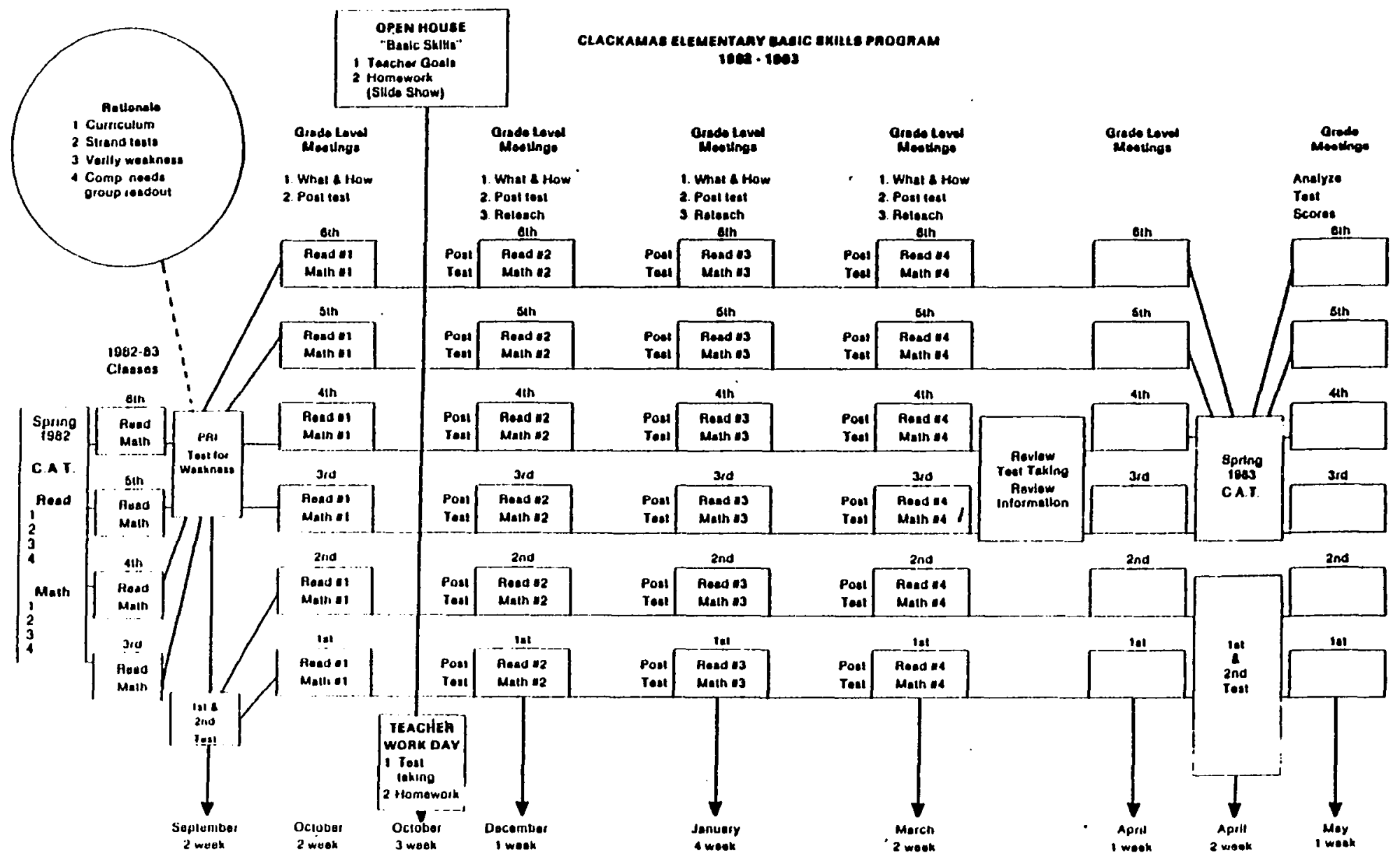


APPENDIX $C$

TEACHER PRI RECORDING SHEET EORM 
Teacher PRI Recording sheet Form

PRI FILE (Skill) NO.

SKILL DESCRIPTION

TEACHER: Mr. Davis

\begin{tabular}{|c|c|c|c|c|c|c|c|c|}
\hline ITS & $\begin{array}{l}\text { PRI } \\
\text { TEST } \\
\text { RESULTS }\end{array}$ & WOF & $\mathrm{KSF}$ & $\mathrm{ET}$ & & $\mathrm{ACT}$ & $\begin{array}{l}\text { OR } \\
\text { ITIES }\end{array}$ & $\begin{array}{l}\text { MASTER } \\
\text { TEST } \\
\text { SCORES }\end{array}$ \\
\hline $\mathrm{Y} B$ & & & & & & & & \\
\hline GE & . & - & - & - & & & $\cdots-$ & $-\cdots$ \\
\hline$\overline{D E E}$ & - & - & - & 一 & - & $-\cdot$ & -- & -- \\
\hline FIELDS & - & - & - & - & - & $-\cdots$ & & -- \\
\hline HER $\overline{\mathrm{FRASER}}$ & $-\cdots$ & - & - & $\cdots$ & - & - - & - & $-\quad-$ \\
\hline$F \bar{R}$ & 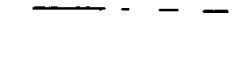 & - & - & - & - & - & -- & $\cdots-$ \\
\hline $\mathrm{N}$ & --- & - & - & - & -. & $\cdots$ & -- & \\
\hline SON HAVEMAN & -. & - & - & 一 & - & $-\cdots$ & $\cdots-$ & --- \\
\hline $\mathrm{LE} \mathrm{K}$ & -- & & $\ldots$ & - & & $\cdots-$ & - & $\cdots-\cdots$ \\
\hline UI $\bar{S} A \bar{C}$ & $\cdots$ & - & - & - & - & - & -- & $\cdots \quad-$ \\
\hline IE MAĒONE & & - & & - & - & & $\cdots-$ & - \\
\hline MANNE & -- & - & & - & - & $-\cdots$ & $-\cdots$ & - \\
\hline DLE M & -- & - & - & $\cdots$ & - & - & $-\ldots$ & $\cdots \cdots$ \\
\hline$E M$ & - & - & $\rightarrow$ & - & - & $\cdots$ & - & -- \\
\hline$\overline{R E E D}$ & -- & -- & & - & & .. - & - & - \\
\hline $\mathrm{ROTH}^{-}$ & $-\quad \cdots--$ & - & - & - & - & - & $-\cdots$ & - \\
\hline BFER SC & $-\cdots-\cdots$ & & & - & & - & $-\ldots$ & \\
\hline & $--\cdots$ & 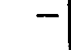 & & & - & -- & - & $-\cdots$ \\
\hline VARTZ & $-1-\bar{c}$ & & & & & & -- & - \\
\hline
\end{tabular}




\section{APPENDIX D \\ TEACHER PRI RECORDING SHEET FORM}

\section{•}


Teacher PRI Recording Sheet Form

PRI FILE (Ski11) NO. 54D

SKILL DESCRIPTION Paragraph paraphrasing-paraphrasing

TEACHER: Mrs. Smith/Mrs. Johnson

\begin{tabular}{|c|c|c|c|c|c|c|c|c|c|c|}
\hline \multirow[t]{2}{*}{ STUDENTS } & \multirow[t]{2}{*}{$\begin{array}{l}\text { PRI } \\
\text { TEST } \\
\text { RESULTS }\end{array}$} & \multicolumn{7}{|c|}{$\begin{array}{l}\text { WORKSHEETS } \\
\text { PRI }\end{array}$} & \multirow[t]{2}{*}{$\begin{array}{c}\text { TUTOR } \\
\text { Activ- } \\
\text { ities- }\end{array}$} & \multirow[t]{2}{*}{$\begin{array}{l}\text { MASTER } \\
\text { TEST } \\
\text { SCORES }\end{array}$} \\
\hline & & 1 & 2 & 3 & 4 & 5 & 6 & 7 & & \\
\hline GINA AFFOLTER & $\mathbf{R}$ & $\mathbf{x}$ & $\mathrm{x}$ & $\mathrm{x}$ & $\mathbf{x}$ & $\mathbf{x}$ & & & & + \\
\hline KRISTY BROWN & - & $\bar{x}$ & $\mathrm{x}$ & $|x|$ & $\mathrm{x}$ & $\mathrm{x}$ & & & & $t$ \\
\hline SHAWN BURHUS & $\bar{R}$ & $\mathrm{x}$ & $\mathrm{x}$ & $\mathrm{x}$ & $\mathrm{x}$ & $\mathrm{x}$ & & & & $t$ \\
\hline MICHAEL COTTIS & $\bar{R}$ & $\mathrm{x}$ & $\bar{x}$ & $\mathrm{x}$ & $\mathrm{x}$ & $\mathrm{x}$ & & & & + \\
\hline CARRINGTON EXTON & $\overline{\mathbf{R}}$ & $\mathrm{x}$ & $\mathrm{x}$ & $x$ & $\mathrm{x}$ & $x$ & & & & \pm \\
\hline BRIAN HAVEMAN & $\bar{R}$ & $\mathrm{x}$ & $\mathrm{x}$ & $\mathrm{x}$ & $\mathrm{x}$ & $\mathrm{x}$ & & & & + \\
\hline $\begin{array}{l}\text { TOM } \\
\text { HEIDENREICH }\end{array}$ & + & $\mathbf{x}$ & $\mathrm{x}$ & $|x|$ & $|x|$ & $\mathrm{x}$ & & & & + \\
\hline MICHELLE KIBBONS & - & $\bar{x}$ & $x$ & $x$ & $x$ & $\frac{x}{x}$ & & & & - \\
\hline LISA KUNDERT & \pm & $x$ & $\mathrm{x}$ & $\mathrm{x}$ & $\mathrm{x}$ & $\mathrm{x}$ & & & & + \\
\hline TERRI PENN & + & $\mathrm{x}$ & $\mathrm{x}$ & $x$ & $\mathrm{x}$ & $\mathrm{x}$ & & & & \pm \\
\hline DON PHILLIPS & $=$ & $\mathrm{x}$ & $\mathrm{x}$ & $\mathrm{x}$ & $\mathrm{x}$ & $\mathbf{x}$ & & & & $\mathrm{R}$ \\
\hline LISA SHORT & - & $\mathrm{x}$ & $\mathrm{x}$ & $\mathrm{x}$ & $\mathrm{x}$ & $\mathrm{x}$ & & & & $\bar{R}$ \\
\hline WENDY SMEAD & $t$ & $\mathrm{x}$ & $\mathrm{x}$ & $\mathrm{x}$ & $\mathbf{x}$ & $\mathbf{x}$ & & & & $t$ \\
\hline NATALIE SMITH & \pm & $x$ & $\mathbf{x}$ & $\mathrm{x}$ & $\mathrm{x}$ & $\mathrm{x}$ & & & & + \\
\hline SCOTT SOFICH & $=$ & $\mathrm{x}$ & $\mathbf{x}$ & $\mathrm{x}$ & $x$ & $\mathrm{x}$ & & & & $t$ \\
\hline MITCHELL STONE & $\mathrm{R}$ & $\mathrm{x}$ & $\mathrm{x}$ & $\mathbf{x}$ & $\mathrm{x}$ & $\mathrm{x}$ & & & & $t$ \\
\hline SUSAN STONEKING & $=$ & $x$ & $\mathrm{x}$ & $\mathbf{x}$ & $\mathrm{x}$ & $\mathbf{x}$ & & & & - \\
\hline SUZANNE THOMAS & + & $\mathrm{x}$ & $\mathrm{x}$ & $\mathbf{x}$ & $\mathbf{x}$ & $\mathbf{x}$ & & & & + \\
\hline DUANE WORLEY & - & $\mathrm{x}$ & $x$ & $\mathrm{x}$ & $\mathrm{x}$ & $\mathrm{x}$ & & & & $=$ \\
\hline SHAWN WYMORE & $=$ & $\mathrm{x}$ & $\mathrm{x}$ & $\mathrm{x}$ & $\mathrm{x}$ & $\mathrm{x}$ & & & & + \\
\hline
\end{tabular}




\section{APPENDIX E}

CLACKAMAS ELEMENTARY - HOMEWORK PROGRAM 
CLACKAMAS ELEMENTARY - HOMEWORK PROGRAM

\section{$\underline{\text { PHILOSOPHY }}$}

The staffs at Clackamas and Carver Elementary Schools believe that parents and teachers have a dual responsibility for the education of children. We believe that the quality of the education of our students would be strengthened by an organized effort between home and school that involves ongoing communication between students, parents, and teachers for the purpose of improvement and enrichment of academic skills.

GOALS

1. To promote communication between home and school.

2. To provide practice and reinforcement of skills learned at school.

3. To encourage positive academic time at home.

4. To promote communication between teachers

\begin{tabular}{c|c}
\hline ACTIVITIES & TIMELINE \\
\hline
\end{tabular}

Teachers:

1. Provide folder to carry homework

2. Make up information packet for parents

3. Design feedback system to parents and students to evaluate homework

4. Provide students with homework that reinforces skills that are being taught at school

5. Provide homework at the appropriate instructional level of enrichment

6. Coordinate homework with other teachers of the same students (Chapter I, Learning Specialist, Media Specialist, other teachers)
September 1983

Spring 1983 and

September 1983

September 2983

All Year

When needed

All Year

When needed

All Year

Parents:

1. Establish daily quiet time for the family

2. Do school work

3. Read aloud and silently

4. Talk and Listen

5. Play games

6. Visit the Library

7. Conference with teacher

All Year

All Year

All Year

All Year

All Year

All Year

All Year 


\begin{tabular}{l|l}
\hline \multicolumn{1}{c}{ Activities } & Timeline \\
\hline $\begin{array}{l}\text { 8. Observe your child in the classroom } \\
\text { 9. Help children take responsibility }\end{array}$ & Yll Year \\
$\begin{array}{l}\text { of returning homework to school } \\
\text { 10. Provide the necessary tools to }\end{array}$ & All Year \\
$\begin{array}{l}\text { accomplish homework } \\
\text { 11. Be positive and encouraging }\end{array}$ & All Year \\
\hline Teachers and Parents & September 1983 \\
\hline $\begin{array}{l}\text { 1. Meet at school to explain homework } \\
\text { 2. Conference together when needed }\end{array}$ & All Year \\
3. Track children's progress & \\
4. Complete a written evaluation of & Mrogram at the end of the school \\
$\quad$\begin{tabular}{l} 
year 1984 \\
\hline
\end{tabular}
\end{tabular}




\section{APPENDIX F CLACKAMAS ELEMENTARY DISCIPLINE POLICY}


Clackamas Elementary Discipline Policy

\section{DISCIPLINE}

Disciplinary procedures are designed to promote the safety, welfare and learning of all students at our school. These procedures, as described below, are in compliance with the District N.C. No. 12 policies, including the Rights and Responsibilities Handbook. A study of the many rules the children must follow at school revealed three rules which, when violated, cause the greatest harm and disruption. These rules are:

1. Assault of another student or any school employee (fighting).

2. Willful disobedience of a staff member.

3. Use of profane or obscene language or gestures.

When one of these incidents occur, it is in the best interest of the school to remove the student(s) from school for the remainder of the day. We feel that limiting this action to three rules, all of the students will be able to remember them and know the consequences. We realize this procedure may be inconvenient for some parents, but it is our intent to provide all students with as safe and wholesome learning environment. If a child is to be sent home, parents will be notified that there has been a problem and arrangements will be made to get the child home. Students will be given work to do at home and will bring this complete to their teacher the following school day. The teacher may also contact the home to provide you with the information they have about the problem, and work with you toward finding a solution so this problem will not occur again. If a problem should occur a second time, the student will again be suspended for one day; however, a parent-teacher-principal conference will be necessary. A third offense of this nature will result in a (2) two day suspension and a parent-teacher-principal conference to determine further action. Generally, discipline here at Clackamas Elementary is good, with most of the students being cooperative in their relationships with other students and staff. We do not anticipate many problems regarding these three basic rules, but when they do arise, we will need your support to deal with them effectively. 
APPENDIX G

CLACRAMAS ELEMENTARY TIME-CUT PROCEDURE 


\section{Clackamas Elementary's Time-Out Procedure}

\section{DESCRIPTION OF TIME-OUT PROCEDURES}

Time-out system: This system is designed to provide student with adequate supervision, whenever it becomes necessary to remove them from the classroom or other school activity. "Time-Outs" may be used for health reasons, catching up on school work, or disruptive behavior.

If, during any grading period, a student receives five (5) time-outs in any one category, the parents will be notified by the teacher. Should this pattern be repeated (a total of ten times) during the same grading period, the ERP/Principal will contact the parents and arrange a conference between the parents, teacher and ERP/Principal.

During this conference, a plan will be designed for dealing with future problems. 
APPENDIX H (1)

TEACHER SURVEY GIVEN AT END OF TREATMENT PROCEDURE 


\title{
TEACHER SURVEY GIVEN AT END OF TREATMENT
}

\section{EVALUATION OF BASIC SKILLS PROGRAM}

\begin{abstract}
Purpose:
The purpose of the survey is to gain information about the attitudes of the teachers who were involved in the Basic Skills Program 1982-83. The information will be used to draw conclusions about the results of the program and will be used for future planning.
\end{abstract}

\section{Confidentiality:}

It will not be necessary to identify yourself on this survey. The results will be evaluated as whole group data, however identifying your grade level is important as different aged students might have different needs and thus a break down of data at different levels might be important.

Time:

This evaluation will take 5 minutes to fill out. 
APPENDIX H (2)

TEACHER SURVEY GIVEN AT END OF TREATMENT PROCEDURE 
Grade Leve1

Strongly

Agree
Strongly

Disagree

1. Low scores on the California Achievement Test should be Analyzed so that weak Academic areas can be identified

2. Students of low socio/ economic backgrounds can be expected to perform at a low academic level

3. Building standards and procedures for involving parents should be developed

4. Parents should be made aware of the building standards and procedures that involve parents

5. Administrators should work with staff to plan ways to improve the academic weak areas of the students as determined by the California Achievement Test

6. Programs should be developed that would improve the weak California Achievement Test Scores

7. Teachers should reteach lesson content until students show they have learned it

8. Teachers should give students homework to help improve basic skills

9. Administrators should monitor and evaluate improvement changes according to criterla established with staff cooperation 
Strongly

Agree
Agree
Strongly

Disagree

10. Administrators should coordinate staff improvement efforts and continue keeping track of student achievement data to access progress toward goals

11. Bringing up Callfornia Achievement Test scores would improve skills children need to improve

12. Teachers should reduce some priority goals for certain low performing students

13. Whole-group instruction to teach skills is preferable

14. Acquisition of baslc skills should take precedence over other school activities

15. Administrators should once a year head up renewal efforts to keep improvements in tune with changing needs

16. California Achievement Test is an achievement test that tests grade level expecations for my grade level

17. Measured progress of a student from a low socio/economic background can be expected to be slow

15. Small groups should be formed when needed to make sure all students learn thoroughly

19. Parents should know their responsibilities for helping students learn

20. Staff members should provide parents with information and techniques for helping students learn 
Strongly

Agree
Agree
Strongly

Disagree

21. Teachers can teach all students all students can master priority objectives

22. The Prescriptive Reading Inventory (PRI) revealed important information about students skills

23. The PRI student worksheets that were used to teach skills were excellent teaching tools

24. The PRI strand test that measured if a skill was mastered was an accurate measurement

25. It was important to record student PRI pretest results and the PRI posttest results so that progress could be determined

26. Meeting every six weeks at grade level meetings helped me plan my lesson plans that would include work on weak academic areas

27. Meeting every six weeks at grade level meetings helped monitor pupll progress in relation to Basic Skills teaching objectives

29. Instead of grade level meetings $I$ would rather plan my own program by myself that will teach to weak academic areas

29. Instead of grade level meetings I would rather plan with the teacher my grade level without. help from administration

30. The involvement of administration in the grade level meetings was an unnecessary intrusion into my teaching practices 
Strongly

31. It is important to teach test taking skills to students so that the achievement test results will be a measure of learning.

32. The Basic Skills Program was an effective way to Improve weak areas

33. If there was improvement of weak areas, I belleve that my own teacher materials are to be credited and not the Basic Skills materials

34. Teachers' motivation was high as they implemented the Basic Skills Program

35. Students' motivation was high as they went through the Basic Skills Program

36. Students were rewarded for academic achlevement and for excellence in behavior 
1. How much time did you spend per week on the "Basic skills Program"?

(approximately)

2. Generally how were the PRI materials presented to your class

3. How would you change the Basic Skills Program to improve weak areas next year?

Please comment on the following:

PRI materials:

Grade Level Meetings:

Parent Involvement:

What materials I would use to teach low areas:

Involvement from the administration:

Monitoring progress:

Teaching test taking skills: 